\title{
Missing Events in Event Studies: Identifying the Effects of Partially Measured News Surprises ${ }^{\dagger}$
}

\author{
By Refet S. Gürkaynak, Burçin KisacıKoĞLu, and Jonathan H. Wright**
}

\begin{abstract}
Macroeconomic news announcements are elaborate and multidimensional. We consider a framework in which jumps in asset prices around announcements reflect both the response to observed surprises in headline numbers and to latent factors, reflecting other news in the release. Non-headline news, for which there are no expectations surveys, is unobservable to the econometrician but nonetheless elicits a market response. We estimate the model by the Kalman filter, which efficiently combines OLS and heteroskedasticity-based event study estimators in one step. With the inclusion of a single latent surprise factor, essentially all yield curve variance in event windows are explained by news. (JEL C51, E43, E52, G12, G14)
\end{abstract}

Macroeconomic news announcements are complex and multidimensional. We argue that recognizing this multidimensionality is essential to understanding the asset price responses to news announcements. We develop the methodology to efficiently estimate asset price reactions to surprises in data releases, some dimensions of which may be unobservable to the econometrician because only some items in data releases have associated expectations surveys, i.e., surprises are only partially measured. We find that, unlike what was thought in the event-study literature so far, news explains almost all of the yield curve movements in event windows.

High-frequency financial event studies are essential tools of analysis that relate asset prices to macroeconomics. It is notoriously difficult to establish causality among movements in macroeconomic variables and asset prices due to simultaneity and endogeneity, but the event study literature properly identifies the reaction of asset prices to news releases, such as the employment report, GDP, or Federal Open Market Committee (FOMC) policy announcements. It exploits the lumpy manner in which news is released to the public as a powerful source of identification since within short windows (daily or higher frequency) around news releases, it is clear

\footnotetext{
* Gürkaynak: Department of Economics, Bilkent University, CEPR, CESIfo, and CFS (email: refet@bilkent. edu.tr); Kısacıkoğlu: Department of Economics, Bilkent University (email: bkisacikoglu @ bilkent.edu.tr); Wright: Department of Economics, Johns Hopkins University, and NBER (email: wrightj@jhu.edu). Gita Gopinath was the coeditor for this article. We are grateful to three anonymous referees, Eric Swanson, and many seminar and conference participants for helpful comments on an earlier draft. We thank Yunus Can Aybaş and Cem Tütüncü for outstanding research assistance. Gürkaynak's research was supported by funding from the European Research Council (ERC) under the European Union's Horizon 2020 research and innovation program (grant agreement 726400). All errors are our sole responsibility.

Go to https://doi.org/10.1257/aer.20181470 to visit the article page for additional materials and author disclosure statements.
} 
that asset price changes do not cause news (Faust et al. 2007, Gürkaynak and Wright 2013, Kuttner 2001). One can then interpret the results to make inference on macroeconomic fundamentals and beliefs of market participants about the structure of the economy.

When event studies are carried out by ordinary least squares (OLS) regressions of asset price changes on surprises, as measured by the difference between released values of macroeconomic data and survey expectations for these releases, the effects of surprises on asset prices, especially the yield curve, are statistically and economically significant. However, it is troubling that even in tight intraday windows of 20 minutes around news announcements, event study regressions explain only a small to moderate fraction of asset price changes. An alternative event study methodology, heteroskedasticity-based identification, which was proposed by Rigobon (2003) and applied very elegantly by Rigobon and Sack (2003, 2004, 2005, 2008), argues that the surveys measure true expectations with large errors, hence OLS regressions are subject to classical measurement error. This approach treats the surprises as essentially unobserved but measures their effects by simply knowing that there are certain days on which the variance of that surprise is unusually large. This in turn gives strikingly larger effects compared to OLS event study regression.

The literature has so far treated these two approaches as substitutes: those assuming surveys do not have large measurement errors employ OLS (but find it difficult to explain what drives the majority of yield curve variance in tight event windows), while those assuming survey measurement errors are sizable employ identification by heteroskedasticity (but find it difficult to relate the market reaction in any particular event window to the surprise in the data release in that window). These approaches are united in their treatment of the "event" as the release of a single, specific piece of information that may or may not be properly measured by the econometrician.

Events, however, are multidimensional. For example, the US employment report that is generally released on the first Friday of each month includes aggregate employment in nonfarm payrolls, the civilian unemployment rate, and average hourly earnings. The OLS event-study literature focuses on the effects of surprises in these numbers. But the employment report also includes around 40 pages of other data. Alas, there are no survey expectations for these other elements, which also elicit a market response to the extent that some of those numbers contain updates to market participants' information sets.

Hence in this paper, we argue that there are surprises in data releases in addition to the headline surprises for which we have survey expectations. If the headline surprises are correctly measured, the OLS event-study estimator gives an unbiased estimate of the effect of the headline surprise, and the standard heteroskedasticity-based estimator is biased. We propose a model in which the non-headline surprises can be represented as a latent unobservable component that is present around macroeconomic announcements, but not at other times. We show that the latent component can separately be estimated by heteroskedasticity-based identification.

The headline surprises are indeed correctly measured; they pass standard rationality tests and outperform simple benchmarks (Balduzzi, Elton and Green 2001; McQueen and Roley 1993; Pearce and Roley 1985). We provide further evidence on this, showing that survey-based expectations fare similarly to market-based expectations. Thus, we argue that it is appropriate to treat the headline surprise as observed 
and recognize that announcements contain information beyond the headline number. The identifying assumption for the latent news is simple: there is more macroeconomic news around the times of announcements than at other times. We present the methodology to estimate the model efficiently via the Kalman filter. The results show that the headline surprise combined with a single latent news factor that captures macroeconomic and monetary policy news can explain a great majority of the yield curve movements around news announcements.

We relate the latent news factor to FOMC statements around monetary policy releases and to nonsurveyed parts of news around other macroeconomic data releases. The significant increase in explanatory power remains when we allow for release-specific latent factors rather than a common one and when we allow for a background noise factor that is there regardless of whether an announcement occurs. The latent factor that we identify is indeed related to news and is not picking up a level factor that is always in the data.

Our contribution is therefore in two dimensions. The methodological contribution is showing that OLS and heteroskedasticity-based identification are complements rather than substitutes and developing an efficient method to combine these to measure the yield curve reaction to both observed and unobserved surprises in macroeconomic data releases. The economic contribution is to show that, using this method, we understand almost all of the yield curve movements in event windows and are able to get a handle on what moves yields, at least at times of macroeconomic releases.

We also show that the same factor helps better explain the stock price reaction to news, even when the factor is extracted only from yields. Market participants perceive multidimensional news in every data release and react to these news similarly; it is only the econometrician who observes some but not all parts of the news. Further, both observed and latent news elicit a hump-shaped response from expected short rates when the yield curve reaction is decomposed into expected short rates and term premia. That hump-shaped change in market participants' expectations of future short rates is strikingly similar to the VAR-based impulse responses of actual short rates to macroeconomic shocks.

The plan for the remainder of this paper is as follows. In Section I, we discuss the event study methodology, showing how it can be implemented via OLS or via heteroskedasticity-based identification, and reporting results using both methods. In Section II we discuss why these methods are complements rather than substitutes and show how they can be simultaneously employed. Section III presents a discussion of the interpretation of the heteroskedasticity-identified latent release factors and goes back to the properties of the survey expectations, showing that the standard reasons to doubt survey-based expectations are very unlikely to be problems in the data used in macroeconomic event studies. This section also provides a demonstration of why it is correct to interpret the heteroskedasticity-based estimator as measuring something conceptually different from the OLS-based event study. Section IV presents robustness checks and extensions. Section V concludes.

\section{Event-Study Methodology}

Macro-finance event studies relate releases of macroeconomic data and changes in asset prices to each other. For example, we may be interested in learning how, say, 
the five-year yield reacts to the non-farm payrolls release. We will denote the news, or unexpected, component of the macro series or monetary policy decision being released as $s_{t}$. With forward-looking investors the log return of the asset or change in yield, $y_{t}$, depends on the change in the information set, and hence on $s_{t}$. This is why expectations surveys are important for macroeconomic news releases: they allow us to construct the unexpected component of the data release, which should drive changes in asset prices.

The general modeling setup is a system of a scalar asset price return in a window around an event being related to a surprise that may be measured with error (Rigobon and Sack 2008): 1

$$
\begin{aligned}
& y_{t}=\beta s_{t}^{*}+\varepsilon_{t}, \\
& s_{t}=s_{t}^{*}+\eta_{t},
\end{aligned}
$$

where $s_{t}^{*}$ is the true surprise (unobservable to the econometrician), $s_{t}$ is the observed surprise, and $\varepsilon_{t}$ and $\eta_{t}$ are uncorrelated error terms. The parameter of interest is the scalar $\beta$, but it is not identified due to $s_{t}^{*}$ being unobservable. There are two ways of identifying $\beta$, via OLS and via heteroskedasticity-based identification.

\section{A. OLS Identification in Event Studies}

If we think that measurement error is negligible, $s_{t}=s_{t}^{*}$, then the surprise is observable and equation (1) can simply be estimated by an OLS regression of $y_{t}$ on $s_{t}$ over announcement windows:

$$
y_{t}=\beta s_{t}+\varepsilon_{t} .
$$

Equation (3) is the standard simple implementation of the event-study methodology that only requires basic OLS and the interpretation of the result is straightforward. The equation fit should be perfect if $s_{t}$ is the only source of variation in this window. This method requires data on expectations of upcoming announcements, but these are available from surveys, notably the long-running survey by Action Economics, which is the successor to Money Market Services (MMS), or alternatively from the Bloomberg Survey.

Table 1 shows the results of such OLS-based event studies for non-farm payrolls, GDP, unemployment, durable goods orders, CPI, core CPI, PPI, core PPI, retail sales, retail sales excluding autos, average hourly earnings, the employment cost index, initial claims, and FOMC policy announcements concerning the target funds rate. The asset returns are changes in yields on the first and fourth Eurodollar futures contracts, and on 2-, 5-, 10-, and 30-year Treasury futures from Tickdata (2020). The windows that we are using are from 5 minutes before the data release and FOMC policy announcement times, to 15 minutes afterward. Expectations are measured

\footnotetext{
${ }^{1}$ Including simultaneity and endogeneity into this system is easy and does not change our results. We do not do so both because it leads to cluttered notation and more importantly because it is very hard to envision how these may be issues in high-frequency event studies of the type that we are looking at.
} 
Table 1-OLS Estimates of Equation (3)

\begin{tabular}{|c|c|c|c|c|c|c|}
\hline & ED1 & ED4 & 2-year & 5-year & 10-year & 30-year \\
\hline Non-farm & $\begin{array}{c}2.87 \\
(0.31)\end{array}$ & $\begin{array}{c}5.64 \\
(0.49)\end{array}$ & $\begin{array}{c}4.46 \\
(0.39)\end{array}$ & $\begin{array}{c}5.26 \\
(0.43)\end{array}$ & $\begin{array}{c}3.96 \\
(0.32)\end{array}$ & $\begin{array}{c}2.41 \\
(0.21)\end{array}$ \\
\hline Initial claims & $\begin{array}{l}-0.31 \\
(0.04)\end{array}$ & $\begin{array}{c}-0.70 \\
(0.08)\end{array}$ & $\begin{array}{c}-0.59 \\
(0.06)\end{array}$ & $\begin{array}{l}-0.66 \\
(0.06)\end{array}$ & $\begin{array}{c}-0.54 \\
(0.05)\end{array}$ & $\begin{array}{l}-0.32 \\
(0.04)\end{array}$ \\
\hline Durable & $\begin{array}{c}0.38 \\
(0.11)\end{array}$ & $\begin{array}{c}0.72 \\
(0.21)\end{array}$ & $\begin{array}{c}0.69 \\
(0.18)\end{array}$ & $\begin{array}{c}0.82 \\
(0.19)\end{array}$ & $\begin{array}{c}0.58 \\
(0.15)\end{array}$ & $\begin{array}{c}0.37 \\
(0.09)\end{array}$ \\
\hline Emp cost & $\begin{array}{c}0.69 \\
(0.20)\end{array}$ & $\begin{array}{c}1.57 \\
(0.45)\end{array}$ & $\begin{array}{c}1.02 \\
(0.35)\end{array}$ & $\begin{array}{c}1.48 \\
(0.43)\end{array}$ & $\begin{array}{c}1.15 \\
(0.33)\end{array}$ & $\begin{array}{c}0.74 \\
(0.23)\end{array}$ \\
\hline Retail & $\begin{array}{c}0.31 \\
(0.17)\end{array}$ & $\begin{array}{c}0.66 \\
(0.21)\end{array}$ & $\begin{array}{c}0.53 \\
(0.18)\end{array}$ & $\begin{array}{c}0.54 \\
(0.22)\end{array}$ & $\begin{array}{c}0.38 \\
(0.19)\end{array}$ & $\begin{array}{c}0.14 \\
(0.14)\end{array}$ \\
\hline Retail ex. auto & $\begin{array}{c}0.40 \\
(0.15)\end{array}$ & $\begin{array}{c}0.83 \\
(0.23)\end{array}$ & $\begin{array}{c}0.87 \\
(0.20)\end{array}$ & $\begin{array}{c}1.16 \\
(0.23)\end{array}$ & $\begin{array}{c}0.92 \\
(0.19)\end{array}$ & $\begin{array}{c}0.71 \\
(0.13)\end{array}$ \\
\hline GDP & $\begin{array}{c}0.67 \\
(0.14)\end{array}$ & $\begin{array}{c}1.62 \\
(0.33)\end{array}$ & $\begin{array}{c}1.19 \\
(0.24)\end{array}$ & $\begin{array}{c}1.59 \\
(0.30)\end{array}$ & $\begin{array}{c}1.21 \\
(0.25)\end{array}$ & $\begin{array}{c}0.70 \\
(0.17)\end{array}$ \\
\hline CPI & $\begin{array}{c}0.01 \\
(0.10)\end{array}$ & $\begin{array}{l}-0.07 \\
(0.22)\end{array}$ & $\begin{array}{l}-0.08 \\
(0.15)\end{array}$ & $\begin{array}{c}0.10 \\
(0.20)\end{array}$ & $\begin{array}{c}0.15 \\
(0.16)\end{array}$ & $\begin{array}{c}0.19 \\
(0.12)\end{array}$ \\
\hline Core CPI & $\begin{array}{c}0.73 \\
(0.12)\end{array}$ & $\begin{array}{c}1.48 \\
(0.21)\end{array}$ & $\begin{array}{c}1.19 \\
(0.17)\end{array}$ & $\begin{array}{c}1.56 \\
(0.21)\end{array}$ & $\begin{array}{c}1.27 \\
(0.17)\end{array}$ & $\begin{array}{c}0.81 \\
(0.12)\end{array}$ \\
\hline PPI & $\begin{array}{c}0.11 \\
(0.10)\end{array}$ & $\begin{array}{c}0.21 \\
(0.17)\end{array}$ & $\begin{array}{c}0.13 \\
(0.14)\end{array}$ & $\begin{array}{c}0.18 \\
(0.16)\end{array}$ & $\begin{array}{c}0.23 \\
(0.13)\end{array}$ & $\begin{array}{c}0.16 \\
(0.09)\end{array}$ \\
\hline Core PPI & $\begin{array}{c}0.61 \\
(0.13)\end{array}$ & $\begin{array}{c}0.95 \\
(0.21)\end{array}$ & $\begin{array}{c}0.82 \\
(0.15)\end{array}$ & $\begin{array}{c}1.03 \\
(0.17)\end{array}$ & $\begin{array}{c}0.89 \\
(0.13)\end{array}$ & $\begin{array}{c}0.68 \\
(0.10)\end{array}$ \\
\hline Hourly earnings & $\begin{array}{c}0.88 \\
(0.25)\end{array}$ & $\begin{array}{c}1.82 \\
(0.34)\end{array}$ & $\begin{array}{c}1.47 \\
(0.27)\end{array}$ & $\begin{array}{c}2.02 \\
(0.34)\end{array}$ & $\begin{array}{c}1.61 \\
(0.27)\end{array}$ & $\begin{array}{c}0.97 \\
(0.18)\end{array}$ \\
\hline Unemp & $\begin{array}{l}-1.23 \\
(0.22)\end{array}$ & $\begin{array}{l}-2.03 \\
(0.37)\end{array}$ & $\begin{array}{c}-1.62 \\
(0.28)\end{array}$ & $\begin{array}{l}-1.70 \\
(0.30)\end{array}$ & $\begin{array}{c}-1.18 \\
(0.23)\end{array}$ & $\begin{array}{l}-0.68 \\
(0.15)\end{array}$ \\
\hline FOMC & $\begin{array}{c}0.57 \\
(0.07)\end{array}$ & $\begin{array}{c}0.44 \\
(0.10)\end{array}$ & $\begin{array}{c}0.28 \\
(0.09)\end{array}$ & $\begin{array}{c}0.14 \\
(0.07)\end{array}$ & $\begin{array}{c}0.03 \\
(0.04)\end{array}$ & $\begin{array}{l}-0.02 \\
(0.02)\end{array}$ \\
\hline$R^{2}$ & 0.40 & 0.36 & 0.37 & 0.36 & 0.34 & 0.30 \\
\hline
\end{tabular}

Notes: White standard errors are in parentheses. Macroeconomic surprises are normalized by their respective standard deviations. Monetary policy surprises are in basis points. Responses of ED1, ED4, 2-year, 5-year, 10-year, and 30 -year yields are in basis points. Regressions are only run on announcement days. The sample is 1992-2018 for macroeconomic announcements, 1992-2007 for monetary policy surprises.

using MMS/Action Economics survey results (Action Economics 2020), except that the FOMC policy surprise is calculated using price changes in short-dated federal funds futures contracts, as proposed by Kuttner (2001) and given in the dataset of Gürkaynak, Sack, and Swanson (2005). A detailed explanation of the data sources and construction is provided in online Appendix Section A.

Our sample period is from January 1992 to December 2018 (except for FOMC surprises, which end in 2007). This includes the period from December 2008 to December 2015 when the United States was stuck at the zero lower bound (ZLB) for short-term nominal interest rates. We could drop this period, but that would greatly reduce the sample size. Swanson and Williams (2014), in their careful study of the effects of ZLB on the sensitivity of asset prices to news, show that while very short-term interest rates were clearly constrained by the ZLB, one- and two-year interest rates were affected for only part of the period, and the sensitivity of longer-term interest rates was essentially unchanged throughout the sample. Hence, 
we use the full sample but in Section IV we show results from a sample ending in 2007 as a robustness check.

The results shown in Table 1 are in line with the literature going back to Fleming and Remolona (1997). In terms of asset price responses, non-farm payrolls is by far the most important macroeconomic release. A one standard deviation non-farm payrolls surprise increases bond yields by 2 to 6 basis points. However, asset price responses to other macroeconomic announcements are also both economically and statistically significant. This pattern is consistent with Gilbert et al. (2017), who show that news with higher intrinsic value, in terms of timeliness and relation to fundamentals, elicits larger asset price responses. We see that yields at all maturities move in the same direction, but we also see a hump-shaped response of yields to macroeconomic announcements, meaning that the medium term maturities are most affected by macro releases. Existing work has shown that headline surprises have similarly shaped effects on the yield curve (Fleming and Remolona 1999) and on the volatility term structure (Bauer 2015). The fact that, while magnitudes are different, the shape of the yield curve response is common to all data surprises will be important when jointly analyzing observed and unobserved surprises below.

For monetary policy surprises, the first Eurodollar futures (ED1) response is larger than for other maturities. This is intuitive because monetary policy decisions affect shorter term maturities the most. The findings reported in this table are also consistent with the literature going back to Kuttner (2001). Nonetheless, even with the very high frequency data that we have, the headline surprises explain at most 40 percent of the variance of yields around news announcements.

The fits of these regressions do not improve noticeably when nonlinear effects are allowed. Figure 1 shows the coefficients of quadratic terms and Figure 2 shows the coefficients of interaction terms when positive and negative surprises are separated. Coefficients of quadratic terms are not statistically different from zero and responses to positive and negative terms are seldom statistically different from each other. More importantly for our purposes, the last panels in both figures show that allowing for these nonlinear effects do not perceptibly change $R^{2}$ measures. ${ }^{2}$ Other nonlinearities, including dependence on macroeconomic state variables, may be present (Goldberg and Grisse 2013), but these are low frequency effects. Our estimated latent factor exhibits no low frequency patterns, and so we do not think that it represents an omitted interaction with low frequency macroeconomic state variables. We conclude that there are other factors that affect yields in the event window and/ or that there is measurement error in the surprises. These are often thought of as the main limitations of the OLS method. Heteroskedasticity-based identification takes these concerns seriously and suggests an alternative way of identifying $\beta$ that allows for classical measurement error in the surprise.

\footnotetext{
${ }^{2}$ The tables underlying these figures are presented in online Appendix Section F. We further show, in Section IV, that widening the event window to 90 minutes or using daily data does not change our conclusions either.
} 

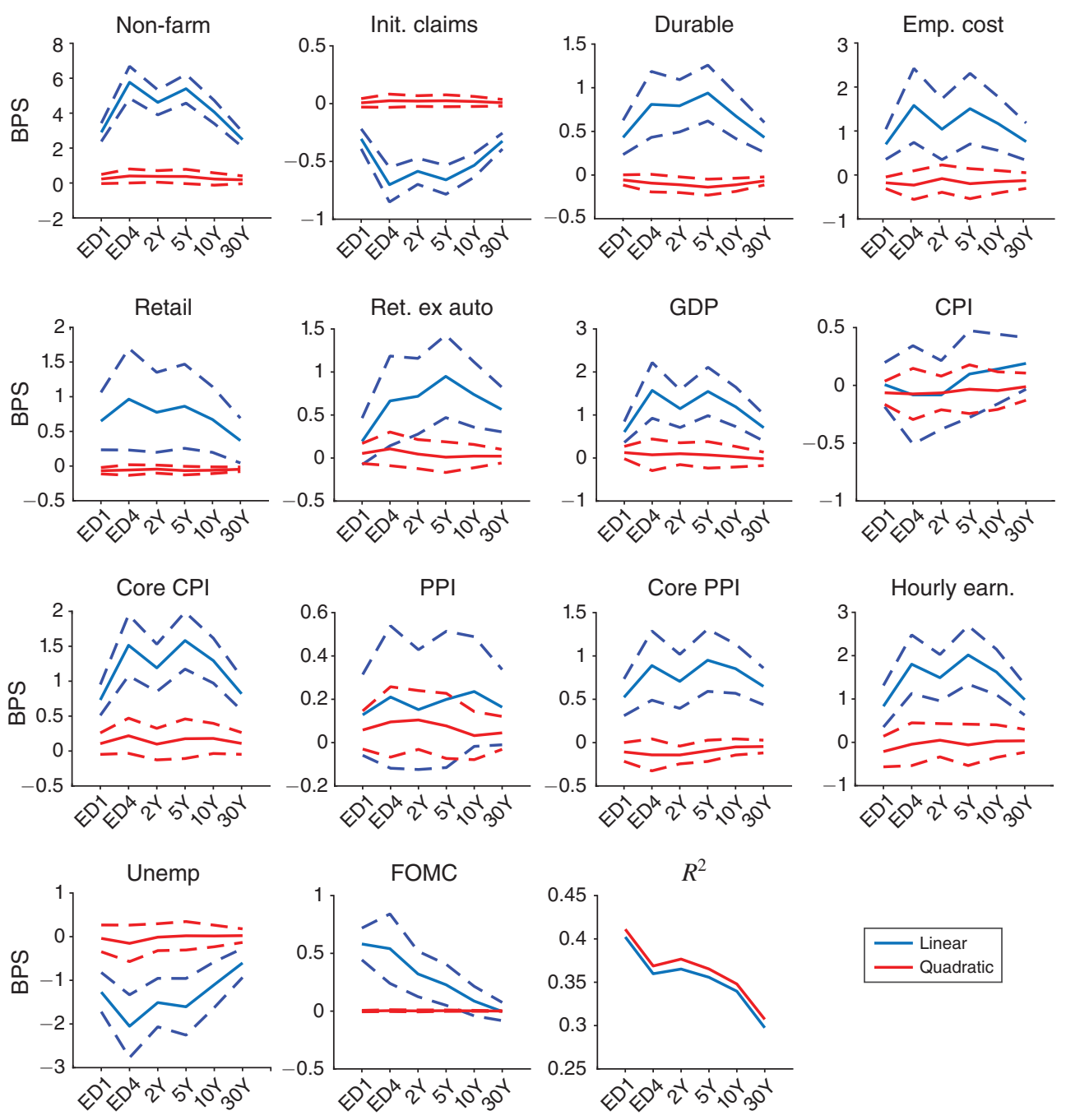

FIGURE 1

Notes: All the subpanels except for the last show coefficient estimates from OLS regressions of yield changes onto headline surprises (blue lines) and squared headline surprises (red lines) for a particular announcement type. The dashed blue and dashed red lines are the respective 95 percent confidence intervals. The last subpanel, labeled $R^{2}$, instead reports the $R^{2}$ values for estimation of the linear regression of yield changes on surprises, shown in blue, and the more flexible model that augments these with squared headline surprises, shown in red.

\section{B. Heteroskedasticity-Based Identification in Event Studies}

The system of equations (1)-(2) contains four parameters, $\beta, \sigma_{\eta}^{2}, \sigma_{\varepsilon}^{2}$, and $\sigma_{*}^{2}$, where $\sigma_{\eta}^{2}, \sigma_{\varepsilon}^{2}$, and $\sigma_{*}^{2}$ are the variances of $\eta_{t}, \varepsilon_{t}$, and $s_{t}^{*}$. The variance-covariance matrix of $\left(y_{t}, s_{t}\right)^{\prime}$ in the event window we are looking at is

$$
\Omega^{E}=\left(\begin{array}{cc}
\beta^{2} \sigma_{*}^{2}+\sigma_{\varepsilon}^{2} & \beta \sigma_{*}^{2} \\
\cdot & \sigma_{*}^{2}+\sigma_{\eta}^{2}
\end{array}\right)
$$



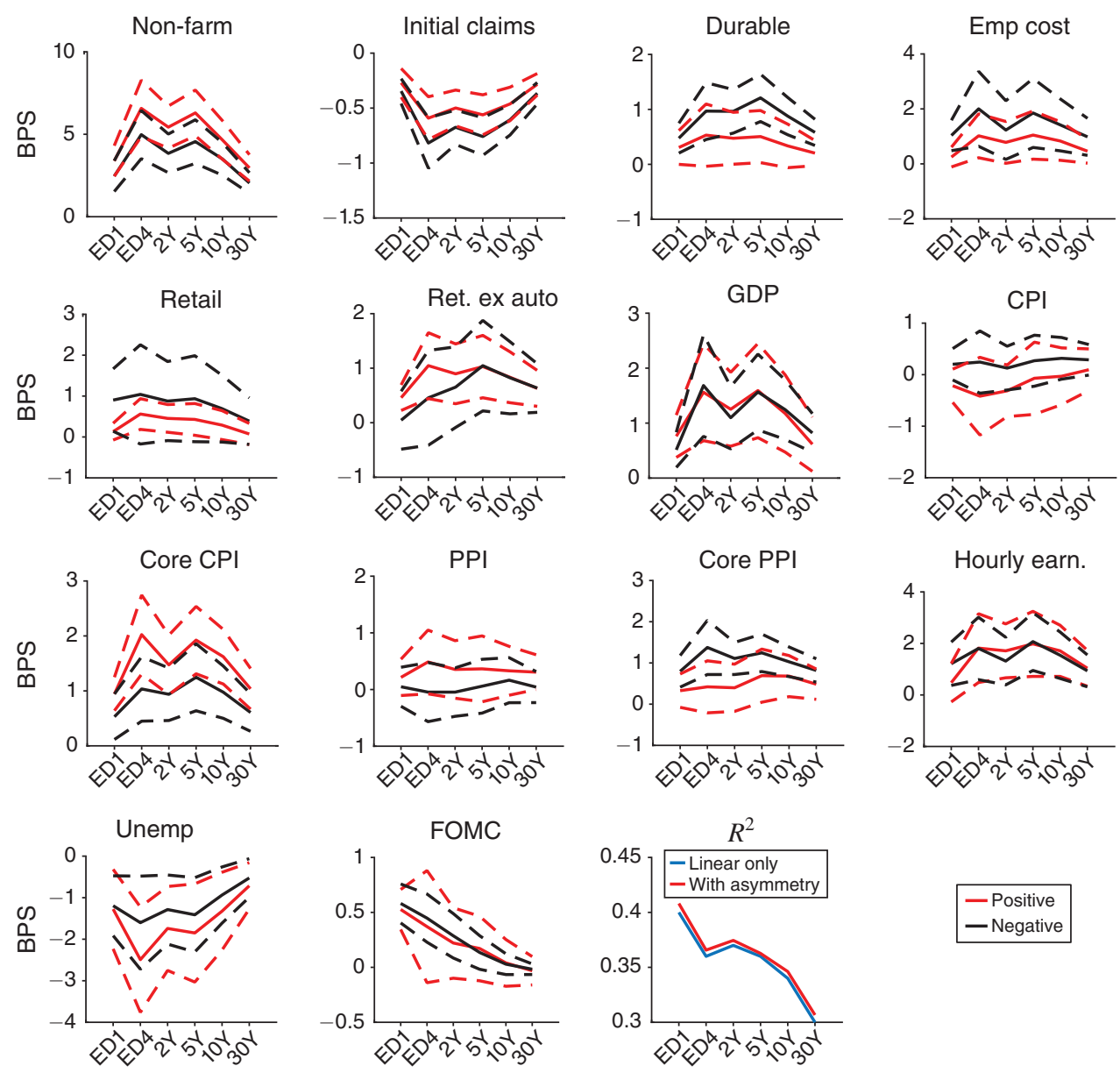

FIGURE 2

Notes: All the subpanels except for the last show coefficient estimates from OLS regressions of yield changes onto positive headline surprises (red lines) and negative headline surprises (blue lines) for a particular announcement type. Under linearity, these should be the same. The dashed red and dashed blue lines are the respective 95 percent confidence intervals. The last subpanel, labeled $R^{2}$, instead reports the $R^{2}$ values for estimation of the linear regression of yield changes on surprises, shown in blue, and the more flexible model that separates out positive and negative headline surprises, shown in red.

which only has three entries, less than the number of parameters. This confirms that $\beta$ is not identified without further assumptions, which we made in the OLS case by asserting that the only relevant source of variation in the event window for the measured surprise is the true surprise $\left(\sigma_{\eta}^{2}=0\right)$. Heteroskedasticitybased identification offers another way of measuring $\beta$ without making that assumption.

The key insight here, going back to Rigobon (2003) and Rigobon and Sack (2004), is that one can also look at windows that contain no event but are otherwise comparable. Think of these windows as a period covering the same length of time, but on a day with no news announcement. In these windows the structure of (1)-(2) 
Table 2-Heteroskedasticity-Based Estimates Following Rigobon (2003) AND Rigobon AND SACK $(2004,2005,2008)$

\begin{tabular}{|c|c|c|c|c|c|c|}
\hline & ED1 & ED4 & 2-year & 5-year & 10-year & 30-year \\
\hline Non-farm & $\begin{array}{c}7.47 \\
(0.71)\end{array}$ & $\begin{array}{l}12.92 \\
(1.03)\end{array}$ & $\begin{array}{c}9.97 \\
(0.71)\end{array}$ & $\begin{array}{l}12.03 \\
(0.86)\end{array}$ & $\begin{array}{c}9.33 \\
(0.70)\end{array}$ & $\begin{array}{c}6.22 \\
(0.50)\end{array}$ \\
\hline Initial claims & $\begin{array}{l}-1.51 \\
(0.50)\end{array}$ & $\begin{array}{l}-2.52 \\
(0.63)\end{array}$ & $\begin{array}{l}-1.72 \\
(0.28)\end{array}$ & $\begin{array}{l}-2.23 \\
(0.29)\end{array}$ & $\begin{array}{l}-1.87 \\
(0.26)\end{array}$ & $\begin{array}{l}-1.35 \\
(0.21)\end{array}$ \\
\hline Durable & $\begin{array}{c}0.93 \\
(1.53)\end{array}$ & $\begin{array}{c}3.28 \\
(1.38)\end{array}$ & $\begin{array}{c}3.39 \\
(0.76)\end{array}$ & $\begin{array}{c}3.52 \\
(0.77)\end{array}$ & $\begin{array}{c}2.94 \\
(0.68)\end{array}$ & $\begin{array}{c}1.98 \\
(0.52)\end{array}$ \\
\hline Emp cost & $\begin{array}{c}3.05 \\
(1.66)\end{array}$ & $\begin{array}{c}3.39 \\
(1.92)\end{array}$ & $\begin{array}{c}2.54 \\
(1.70)\end{array}$ & $\begin{array}{c}3.08 \\
(1.19)\end{array}$ & $\begin{array}{c}2.34 \\
(0.99)\end{array}$ & $\begin{array}{c}1.51 \\
(0.84)\end{array}$ \\
\hline Retail ex. auto & $\begin{array}{c}1.98 \\
(4.50)\end{array}$ & $\begin{array}{c}4.26 \\
(3.44)\end{array}$ & $\begin{array}{c}2.78 \\
(1.38)\end{array}$ & $\begin{array}{c}2.56 \\
(1.30)\end{array}$ & $\begin{array}{c}1.88 \\
(1.17)\end{array}$ & $\begin{array}{c}1.23 \\
(0.69)\end{array}$ \\
\hline GDP (advance) & $\begin{array}{c}7.40 \\
(5.74)\end{array}$ & $\begin{array}{c}7.86 \\
(3.71)\end{array}$ & $\begin{array}{l}5.82 \\
2.97\end{array}$ & $\begin{array}{c}6.63 \\
(3.26)\end{array}$ & $\begin{array}{c}5.46 \\
(2.86)\end{array}$ & $\begin{array}{c}3.04 \\
(1.73)\end{array}$ \\
\hline Core CPI & $\begin{array}{c}2.67 \\
(1.01)\end{array}$ & $\begin{array}{c}5.61 \\
(1.08)\end{array}$ & $\begin{array}{c}3.90 \\
(1.08)\end{array}$ & $\begin{array}{c}4.98 \\
(0.83)\end{array}$ & $\begin{array}{c}3.89 \\
(0.59)\end{array}$ & $\begin{array}{c}2.79 \\
(0.43)\end{array}$ \\
\hline Core PPI & $\begin{array}{c}4.08 \\
(1.28)\end{array}$ & $\begin{array}{c}5.31 \\
(1.42)\end{array}$ & $\begin{array}{c}4.33 \\
(1.15)\end{array}$ & $\begin{array}{c}5.46 \\
(1.39)\end{array}$ & $\begin{array}{c}4.58 \\
(1.13)\end{array}$ & $\begin{array}{c}3.10 \\
(0.69)\end{array}$ \\
\hline FOMC & $\begin{array}{c}0.85 \\
(0.09)\end{array}$ & $\begin{array}{c}1.93 \\
(0.53)\end{array}$ & $\begin{array}{c}1.46 \\
(0.47)\end{array}$ & $\begin{array}{c}3.11 \\
(1.55)\end{array}$ & $\begin{array}{c}6.69 \\
(8.69)\end{array}$ & $\begin{array}{c}-4.09 \\
(5.85)\end{array}$ \\
\hline
\end{tabular}

Notes: Asymptotic standard errors are in parentheses. Macroeconomic surprises are normalized by their respective standard deviations. Monetary policy surprises are in basis points. Responses of ED1, ED4, 2-year, 5-year, 10-year, and 30-year yields are in basis points. The sample is 1992-2018 for macroeconomic announcements, 1992-2007 for monetary policy surprises.

is the same, but there is no surprise. The variance-covariance matrix of $\left(y_{t}, s_{t}\right)^{\prime}$ for the nonevent window is

$$
\Omega^{N E}=\left(\begin{array}{cc}
\sigma_{\varepsilon}^{2} & 0 \\
0 & 0
\end{array}\right)
$$

In the event window, we observe $y_{t}$ and $s_{t}$, and so can estimate $\Omega^{E}$. Call this $\hat{\Omega}^{E}$. In the nonevent window, $s_{t}$ is zero by assumption, and we observe $y_{t}$. We can estimate $\Omega^{N E}$, all elements of which are 0 , except for the 1,1 element, which is informative about the variance of noise. Subtracting (5) from (4) gives

$$
\Omega^{E}-\Omega^{N E}=\left(\begin{array}{cc}
\beta^{2} \sigma_{*}^{2} & \beta \sigma_{*}^{2} \\
\cdot & \sigma_{*}^{2}+\sigma_{\eta}^{2}
\end{array}\right),
$$

from which one can identify the parameter of interest, $\beta$. Concretely, one can simply estimate $\beta$ as $\left(\left[\hat{\Omega}^{E}\right]_{1,1}-\left[\hat{\Omega}^{N E}\right]_{1,1}\right) /\left[\hat{\Omega}^{E}\right]_{1,2}$, as proposed by Rigobon and Sack (2004, 2008).

Table 2 repeats the same exercise that was carried out in Table 1, this time using heteroskedasticity-based identification. It is striking that all the coefficients are much larger when identification via heteroskedasticity is employed compared to OLS, which would be the natural effect of correcting for attenuation bias in the measurement error model. Therefore, a possible interpretation of this finding is that headline news is indeed measured with substantial error, leading to attenuation bias, and that heteroskedasticity-based identification is robust to these problems. This is the interpretation offered by Rigobon and Sack (2008). But $\sigma_{\eta}^{2}$ would have to be 
large compared to $\sigma_{*}^{2}$ for this to be true, and we argue in Section IIIB that this is not the case.

In this paper, we offer a different interpretation, more in line with the evidence showing the broad efficiency of survey expectations of data releases. We argue that survey expectations are measuring headline surprises correctly but instead there are surprise components in news announcements that are not directly observed by the econometrician, which have important effects on asset prices. Our reasons for thinking along these lines, and the proposed methodology to accommodate this feature of the data, are presented in the next section.

\section{Partially Measured News and Heteroskedasticity-Based Identification}

We recognize that data releases are elaborate and multidimensional. The "news" that is captured in OLS-based event studies is only headline news, i.e., the deviation of the headline number from its survey expectation. The survey expectations are well measured and usually pass standard forecast rationality tests. Gürkaynak and Wolfers (2007) find that survey-based forecasts are roughly comparable in efficiency to market-based ones, and we expand on this argument in Section III.

However, it remains the case that the headline news is only part of news releases. Releases also contain other information such as revisions to past data and information on subcomponents. For example, the GDP release reports the contributions of different expenditure items, and markets may react differently to increases in GDP driven by gross fixed capital formation versus inventory increases. Some releases contain a discussion of current conditions and even forecasts. The FOMC release is the obvious example, where the statement has for some time garnered more attention than the immediate policy setting. Yet in terms of "news," only the headline is observable as there are surveys for these numbers alone. The balance of the news in the release is unobservable to the econometrician, but elicits a market response as well. We argue that this is why the $R^{2}$ s of OLS-based event studies are not very high. The regression only captures the contribution of the headline news to the variance of asset prices and effects of all other news in the same release show up in the residual.

Notice that under this interpretation, the OLS-based event study answers a narrowly defined question correctly: it determines the relationship between the headline news (but not the whole news release) and the asset price in question. The heteroskedasticity-based estimator instead allows the news to be unobservable and conditions only on the time of the data release. To the extent that news is multidimensional, the increase in variance at the time of the release is due to more than the headline surprise. The heteroskedasticity-based estimator captures the asset price response to the news release as a whole, not only to the headline number. This, rather than sizable measurement error in survey expectations, is why the heteroskedasticity-based estimator always finds larger asset price response coefficients. In the next section, we show this analytically, and bring direct evidence to verify that heteroskedasticity-based estimator, along with the headline surprise effects, captures the effects of non-headline component of the release.

We therefore posit that a complete understanding of yield changes in news release event windows is possible, using OLS to partial out the effects of the observable news on the asset prices, and then using heteroskedasticity-based identification to 
learn the effect of non-headline, unobservable news in the data release. This could be done in two steps, with heteroskedasticity-based identification applied to residuals from the OLS regression ${ }^{3}$ but we instead introduce an efficient, one-step estimator via the Kalman filter. This has the useful by-product of giving an estimate of the unobserved news component in any given data release, which is not directly available from identification through heteroskedasticity.

We let $y_{t}$ denote the $6 \times 1$ vector of yield changes (of maturities studied in Tables 1 and 2) from 8:25AM to 8:45 AM. Some days have macroeconomic announcements at 8:30AM, while others do not, but all the macroeconomic announcements that we consider come out at 8:30AM. In the implementation for FOMC policy surprises, we let $y_{t}$ denote the $6 \times 1$ vector of yield changes from 2:10PM to 2:30PM (incorporating some minor deviations of timing to accommodate FOMC announcements times). Monetary policy dates and times are from Gürkaynak, Sack, and Swanson (2005) up to December 2004, and from Federal Reserve Board (2020) since then. Data from these intradaily windows are included regardless of whether they contain an announcement.

The model that we specify is then

$$
y_{t}=\beta^{\prime} s_{t}+\gamma^{\prime} d_{t} f_{t}+\varepsilon_{t},
$$

where $s_{t}$ is the vector of observable surprises in macroeconomic or monetary policy announcements, ${ }^{4} d_{t}$ is a dummy that is 1 if there is an announcement in that window and 0 otherwise, $f_{t}$ is an i.i.d. $N(0,1)$ latent variable that is common to all releases, and $\varepsilon_{t}$ is i.i.d. normal with mean zero and diagonal variance-covariance matrix. The sample period and the data used to measure surprises remain the same.

Equation (7) would essentially collapse to the standard OLS event study regression if the $f_{t}$ term were dropped, and to a heteroskedasticity-based estimator if the $s_{t}$ term were dropped. As it stands, this equation can be estimated by maximum likelihood via the Kalman filter. ${ }^{5}$

\section{A. Kalman Filter and Identification}

In our Kalman filter-based method, equation (7) is the measurement equation and the i.i.d. sequence of $\left\{f_{t}\right\}$ is the state. ${ }^{6}$ The Kalman filter provides an orthogonal decomposition $\left(s_{t} \perp f_{t}\right)$ consistent with the idea that $f_{t}$ can also be recovered by heteroskedasticity-based methods from OLS $\left(y_{t}\right.$ on $\left.s_{t}\right)$ residuals, where these residuals would be orthogonal to observable surprises. Thus in essence, $f_{t}$ is identified by the heteroskedasticity of the OLS residuals, where identification requires $d_{t}$ being equal to 1 for some but not all dates (having both event and nonevent dates in the

\footnotetext{
${ }^{3}$ We report the results from doing this in online Appendix Section B.

${ }^{4} s_{t}$ is set to 0 for any announcement that does not take place in that window.

${ }^{5}$ Maximum likelihood estimates are obtained via the EM algorithm. Our code can handle any number of releases, asset price changes, and latent factors and is made available for others to use.

${ }^{6}$ This is an unusual use of the Kalman filter as it is usually employed for data that are serially correlated. The i.i.d. latent variable (surprises by definition will be uncorrelated) is a special case that can be written in state-space form and is recoverable by the Kalman filter.
} 
sample). The variance of $f_{t}$ is normalized to unity as otherwise $\gamma$ would be identified only up to scale.

The Kalman filter estimates the latent factor $f_{t}$ and the effects of the latent and observable $\left(s_{t}\right)$ surprises on yields efficiently. Using a vector of yields is not necessary. As every yield is heteroskedastic, we could estimate $f_{t}$ from any one of them: homoskedasticity of $\epsilon_{t}$ and heteroskedasticity of $f_{t}$ identifies them separately (up to scale) with a non-degenerate $d_{t}$ distribution. Thus, we are not relying on a cross-sectional covariance in the $y_{t}$ vector for identification, ${ }^{7}$ and indeed the $\beta$ coefficient estimates are the same regardless of whether equation (7) is estimated jointly or equation-by-equation. (SUR coefficients are the same as equation by equation OLS when right-hand-side covariates are the same, as is the case here.)

Given the understanding of partially observed, multidimensional data releases presented in this paper, multiple yields and the cross-sectional variance of $y_{t}$ can also be used to identify the latent factor and its effects in a two-step procedure, by first regressing the yield changes on surprises and then extracting the first principal component from OLS residuals. But our Kalman filter approach is preferable for three reasons. First, and most importantly, the two-step procedure that does not employ nonevent window information cannot disentangle common yield curve movements that would be present even without an announcement from those caused by the announcement, whereas our Kalman-filter based method can do this (see Section IV). Second, in contrast to the Kalman filter, two-step methods are inefficient. And third, the two-step method does not work with only a single asset, unlike what we propose here. Online Appendix Section D presents our implementation of the Kalman filter in this context, showing algebraically how the system is identified.

\section{B. Baseline Results}

Table 3 reports the results, along with $R^{2}$ values from the regressions of $y_{t}$ on $s_{t}$ alone, and from regressions augmented with the Kalman-smoothed estimate of $f_{t}$ in equation (7), around announcement times. The headline surprise alone explains less than 40 percent of announcement-window variation in each of the yields considered here, as in Table 1. Augmenting the regression with one latent factor brings the explained share up to over 90 percent. We can explain about all of the movements in the term structure of interest rates around news announcements with the headline surprise and one latent factor. Inclusion of the latent factor makes little difference to the estimated coefficients on the headline surprises due to orthogonality, although it does reduce the error variance and hence the standard errors.

The specification in equation (7) implies that the latent factor has the same loadings for all announcement types and it is worth noting that the $R^{2}$ values are so high despite this constraint. The releases are clearly heteroskedastic, with the employment report creating the largest variance, and so the model is literally misspecified: the draws of $f_{t}$ on employment report days have sample variance greater than 1 . That does not prevent the model from fitting well, which means that different announcements have similar relative effects on different points of the yield curve.

\footnotetext{
${ }^{7}$ We will use cross-sectional covariance and will need multiple assets in Section IVB when we also allow for a factor that is present in both event and nonevent windows.
} 
TABle 3-Estimates of Equation (7)

\begin{tabular}{|c|c|c|c|c|c|c|}
\hline & ED1 & ED4 & 2-year & 5-year & 10-year & 30-year \\
\hline Non-farm & $\begin{array}{c}2.87 \\
(0.16)\end{array}$ & $\begin{array}{c}5.66 \\
(0.24)\end{array}$ & $\begin{array}{c}4.46 \\
(0.20)\end{array}$ & $\begin{array}{c}5.26 \\
(0.21)\end{array}$ & $\begin{array}{c}3.97 \\
(0.16)\end{array}$ & $\begin{array}{c}2.41 \\
(0.11)\end{array}$ \\
\hline Initial claims & $\begin{array}{l}-0.30 \\
(0.02)\end{array}$ & $\begin{array}{l}-0.71 \\
(0.04)\end{array}$ & $\begin{array}{l}-0.56 \\
(0.03)\end{array}$ & $\begin{array}{l}-0.6 \\
(0.03)\end{array}$ & $\begin{array}{l}-0.53 \\
(0.03)\end{array}$ & $\begin{array}{l}-0.32 \\
(0.02)\end{array}$ \\
\hline Durable & $\begin{array}{c}0.38 \\
(0.06)\end{array}$ & $\begin{array}{c}0.86 \\
(0.10)\end{array}$ & $\begin{array}{c}0.66 \\
(0.08)\end{array}$ & $\begin{array}{c}0.82 \\
(0.09)\end{array}$ & $\begin{array}{c}0.58 \\
(0.08)\end{array}$ & $\begin{array}{c}0.37 \\
(0.05)\end{array}$ \\
\hline Emp cost & $\begin{array}{c}0.68 \\
(0.10)\end{array}$ & $\begin{array}{c}1.49 \\
(0.22)\end{array}$ & $\begin{array}{c}1.14 \\
(0.17)\end{array}$ & $\begin{array}{c}1.48 \\
(0.21)\end{array}$ & $\begin{array}{c}1.15 \\
(0.16)\end{array}$ & $\begin{array}{c}0.74 \\
(0.11)\end{array}$ \\
\hline Retail & $\begin{array}{c}0.31 \\
(0.09)\end{array}$ & $\begin{array}{c}0.74 \\
(0.12)\end{array}$ & $\begin{array}{c}0.60 \\
(0.09)\end{array}$ & $\begin{array}{c}0.54 \\
(0.11)\end{array}$ & $\begin{array}{c}0.38 \\
(0.10)\end{array}$ & $\begin{array}{c}0.14 \\
(0.07)\end{array}$ \\
\hline Retail ex. auto & $\begin{array}{c}0.40 \\
(0.07)\end{array}$ & $\begin{array}{c}0.91 \\
(0.12)\end{array}$ & $\begin{array}{c}0.84 \\
(0.10)\end{array}$ & $\begin{array}{c}1.16 \\
(0.11)\end{array}$ & $\begin{array}{c}0.92 \\
(0.09)\end{array}$ & $\begin{array}{c}0.70 \\
(0.07)\end{array}$ \\
\hline GDP & $\begin{array}{c}0.66 \\
(0.07)\end{array}$ & $\begin{array}{c}1.61 \\
(0.17)\end{array}$ & $\begin{array}{c}1.18 \\
(0.12)\end{array}$ & $\begin{array}{c}1.59 \\
(0.15)\end{array}$ & $\begin{array}{c}1.21 \\
(0.12)\end{array}$ & $\begin{array}{c}0.70 \\
(0.08)\end{array}$ \\
\hline CPI & $\begin{array}{c}0.01 \\
(0.05)\end{array}$ & $\begin{array}{l}-0.07 \\
(0.11)\end{array}$ & $\begin{array}{l}-0.02 \\
(0.08)\end{array}$ & $\begin{array}{c}0.10 \\
(0.10)\end{array}$ & $\begin{array}{c}0.15 \\
(0.08)\end{array}$ & $\begin{array}{c}0.19 \\
(0.06)\end{array}$ \\
\hline Core CPI & $\begin{array}{c}0.72 \\
(0.06)\end{array}$ & $\begin{array}{c}1.66 \\
(0.10)\end{array}$ & $\begin{array}{c}1.24 \\
(0.09)\end{array}$ & $\begin{array}{c}1.56 \\
(0.10)\end{array}$ & $\begin{array}{c}1.27 \\
(0.08)\end{array}$ & $\begin{array}{c}0.81 \\
(0.06)\end{array}$ \\
\hline PPI & $\begin{array}{c}0.10 \\
(0.05)\end{array}$ & $\begin{array}{c}0.25 \\
(0.08)\end{array}$ & $\begin{array}{c}0.18 \\
(0.07)\end{array}$ & $\begin{array}{c}0.18 \\
(0.08)\end{array}$ & $\begin{array}{c}0.23 \\
(0.06)\end{array}$ & $\begin{array}{c}0.16 \\
(0.04)\end{array}$ \\
\hline Core PPI & $\begin{array}{c}0.61 \\
(0.06)\end{array}$ & $\begin{array}{l}1.05 \\
(0.10)\end{array}$ & $\begin{array}{c}0.77 \\
(0.08)\end{array}$ & $\begin{array}{l}1.03 \\
(0.08)\end{array}$ & $\begin{array}{c}0.89 \\
(0.07)\end{array}$ & $\begin{array}{c}0.68 \\
(0.05)\end{array}$ \\
\hline Unemp & $\begin{array}{l}-1.23 \\
(0.11)\end{array}$ & $\begin{array}{l}-2.04 \\
(0.18)\end{array}$ & $\begin{array}{l}-1.64 \\
(0.14)\end{array}$ & $\begin{array}{l}-1.70 \\
(0.15)\end{array}$ & $\begin{array}{l}-1.18 \\
(0.12)\end{array}$ & $\begin{array}{l}-0.68 \\
(0.08)\end{array}$ \\
\hline Hourly earnings & $\begin{array}{c}0.88 \\
(0.12)\end{array}$ & $\begin{array}{c}1.84 \\
(0.17)\end{array}$ & $\begin{array}{c}1.44 \\
(0.14)\end{array}$ & $\begin{array}{c}2.02 \\
(0.17)\end{array}$ & $\begin{array}{c}1.61 \\
(0.13)\end{array}$ & $\begin{array}{c}0.97 \\
(0.09)\end{array}$ \\
\hline FOMC & $\begin{array}{c}0.57 \\
(0.04)\end{array}$ & $\begin{array}{c}0.43 \\
(0.04)\end{array}$ & $\begin{array}{c}0.28 \\
(0.04)\end{array}$ & $\begin{array}{c}0.14 \\
(0.04)\end{array}$ & $\begin{array}{c}0.03 \\
(0.02)\end{array}$ & $\begin{array}{l}-0.02 \\
(0.01)\end{array}$ \\
\hline Factor & $\begin{array}{c}1.37 \\
(0.03)\end{array}$ & $\begin{array}{c}3.14 \\
(0.05)\end{array}$ & $\begin{array}{c}2.42 \\
(0.04)\end{array}$ & $\begin{array}{c}2.94 \\
(0.04)\end{array}$ & $\begin{array}{c}2.28 \\
(0.03)\end{array}$ & $\begin{array}{c}1.46 \\
(0.02)\end{array}$ \\
\hline $\begin{array}{l}R^{2} \text { no factor } \\
R^{2} \text { with factor }\end{array}$ & $\begin{array}{l}0.40 \\
0.73\end{array}$ & $\begin{array}{l}0.36 \\
0.92\end{array}$ & $\begin{array}{l}0.37 \\
0.94\end{array}$ & $\begin{array}{l}0.36 \\
0.98\end{array}$ & $\begin{array}{l}0.34 \\
0.96\end{array}$ & $\begin{array}{l}0.30 \\
0.87\end{array}$ \\
\hline
\end{tabular}

Notes: Standard errors are in parentheses. Macroeconomic surprises are normalized by their respective standard deviations. Monetary policy surprises are in basis points. Responses of ED1, ED4, 2-year, 5-year, 10-year, and 30-year yields are in basis points. The sample is 1992-2018 for macroeconomic announcements, 1992-2007 for monetary policy surprises. The factor is estimated via the Kalman Filter using changes in asset prices around macroeconomic and FOMC releases. The $R^{2}$ values are those of announcement day yields using (i) only headline surprises, (ii) headline surprises and the latent factor.

Nonetheless, we can extend the model to incorporate release-specific factors, specifying instead that

$$
y_{t}=\beta^{\prime} s_{t}+\sum_{i=1}^{I} d_{i t} \gamma_{i} f_{i t}+\varepsilon_{t}
$$

where $d_{i t}$ is a dummy that is 1 if an announcement of the $i$ th type comes out in window $t$ and 0 otherwise and $I$ is the number of latent factors. Because they always come out concurrently, non-farm payroll/unemployment/average hourly earnings, retail sales/retail sales ex autos, core PPI/PPI, and core CPI/CPI surprises each share a single latent factor, and so there are eight latent macroeconomic announcement factors, even though there are 13 8:30AM macroeconomic announcements. 
Including the monetary policy factor, in total we have nine release related factors to be estimated. The factors $\left\{f_{i t}\right\}_{i=1}^{I}$ are all standard normal and are independent over time and independent of each other. This extended model can also be estimated by maximum likelihood via the Kalman filter. The results are reported in Table 4. The coefficient estimates on the headline surprises are similar to those in Tables 1 and 3.

Table 4 also includes the $R^{2}$ values from regressions of elements of $y_{t}$ on $s_{t}$ alone, and from regressions augmented with the Kalman smoothed estimates of the latent factors associated with macro announcements. Incorporating the macro-factors again increases the $R^{2}$ values from below 40 percent to above 90 percent for most maturities. The $R^{2}$ values are similar to the single factor case, even though the single factor model is nested in equation (8). (The $R^{2}$ would not be 1 because the usual market noise, as measured by nonevent window variance of yields, is still in the data.)

In the next two sections we provide a deeper understanding and better intuition for these issues, as well as presenting extensions.

\section{Discussion: Understanding the Latent Factor}

In this section we study the relationship between measurement error, latent factors, OLS, and heteroskedasticity-based estimators. To do so, we analytically explore the implications of different modeling assumptions about the data-generating process on OLS and heteroskedasticity-based estimates and turn to empirical evidence to see which of these are consistent with the data. We then study the properties of the latent factor and show that it is indeed related to non-headline news and discuss how these results help improve our understanding of yield curve movements.

\section{A. A General Model}

The heteroskedasticity-based parameter estimates are larger in absolute value than their OLS counterparts but this is consistent with either attenuation bias from measurement error in the headline surprises or the presence of an unobservable latent factor. The difference in estimates, by itself, does not distinguish between the measurement error and unobserved surprises alternatives. ${ }^{8}$

To show this formally, we consider a general model which incorporates both measurement error and an unobservable latent factor, nesting both cases. Here we discuss the case with scalars for ease of notation. The intuition is identical when $y_{t}$ is a vector, as employed in our application of the Kalman filter. The model is

$$
\begin{aligned}
& y_{t}=\beta s_{t}^{*}+\gamma d_{t} f_{t}+\varepsilon_{t}, \\
& s_{t}=s_{t}^{*}+\eta_{t},
\end{aligned}
$$

\footnotetext{
${ }^{8}$ Another alternative, also discussed by Rigobon and Sack, is that correctly measured news is imperfectly informative about an underlying state of the economy and the market reaction is to the update of that state. This may indeed be the case and that interpretation is consistent with ours as the OLS coefficient would then reflect the mapping between the state and the headline news, and the orthogonal latent factor would be statistically significant and would improve the $R^{2}$ in yield reaction regressions only if non-headline news in the release are independently informative about the underlying state.
} 
Table 4-Estimates of Equation (8)

\begin{tabular}{|c|c|c|c|c|c|c|}
\hline & ED1 & ED4 & 2-year & 5-year & 10-year & 30-year \\
\hline Non-farm & $\begin{array}{c}2.87 \\
(0.16)\end{array}$ & $\begin{array}{c}5.66 \\
(0.24)\end{array}$ & $\begin{array}{c}4.46 \\
(0.20)\end{array}$ & $\begin{array}{c}5.27 \\
(0.21)\end{array}$ & $\begin{array}{c}3.97 \\
(0.16)\end{array}$ & $\begin{array}{c}2.41 \\
(0.11)\end{array}$ \\
\hline Initial claims & $\begin{array}{l}-0.31 \\
(0.02)\end{array}$ & $\begin{array}{l}-0.72 \\
(0.03)\end{array}$ & $\begin{array}{l}-0.58 \\
(0.02)\end{array}$ & $\begin{array}{l}-0.68 \\
(0.03)\end{array}$ & $\begin{array}{l}-0.55 \\
(0.02)\end{array}$ & $\begin{array}{l}-0.33 \\
(0.02)\end{array}$ \\
\hline Durable & $\begin{array}{c}0.40 \\
(0.06)\end{array}$ & $\begin{array}{c}0.88 \\
(0.11)\end{array}$ & $\begin{array}{c}0.69 \\
(0.09)\end{array}$ & $\begin{array}{c}0.85 \\
(0.10)\end{array}$ & $\begin{array}{c}0.60 \\
(0.08)\end{array}$ & $\begin{array}{c}0.39 \\
(0.05)\end{array}$ \\
\hline Emp cost & $\begin{array}{c}0.68 \\
(0.10)\end{array}$ & $\begin{array}{c}1.47 \\
(0.22)\end{array}$ & $\begin{array}{c}1.12 \\
(0.17)\end{array}$ & $\begin{array}{c}1.46 \\
(0.21)\end{array}$ & $\begin{array}{c}1.13 \\
(0.16)\end{array}$ & $\begin{array}{c}0.73 \\
(0.11)\end{array}$ \\
\hline Retail & $\begin{array}{c}0.25 \\
(0.08)\end{array}$ & $\begin{array}{c}0.61 \\
(0.10)\end{array}$ & $\begin{array}{c}0.49 \\
(0.08)\end{array}$ & $\begin{array}{c}0.40 \\
(0.09)\end{array}$ & $\begin{array}{c}0.27 \\
(0.08)\end{array}$ & $\begin{array}{c}0.06 \\
(0.06)\end{array}$ \\
\hline Retail ex. auto & $\begin{array}{c}0.44 \\
(0.07)\end{array}$ & $\begin{array}{c}1.02 \\
(0.12)\end{array}$ & $\begin{array}{c}0.92 \\
(0.09)\end{array}$ & $\begin{array}{c}1.26 \\
(0.11)\end{array}$ & $\begin{array}{c}1.00 \\
(0.09)\end{array}$ & $\begin{array}{c}0.76 \\
(0.06)\end{array}$ \\
\hline GDP & $\begin{array}{c}0.64 \\
(0.07)\end{array}$ & $\begin{array}{c}1.58 \\
(0.15)\end{array}$ & $\begin{array}{c}1.16 \\
(0.10)\end{array}$ & $\begin{array}{c}1.56 \\
(0.13)\end{array}$ & $\begin{array}{c}1.18 \\
(0.11)\end{array}$ & $\begin{array}{c}0.68 \\
(0.07)\end{array}$ \\
\hline CPI & $\begin{array}{c}0.01 \\
(0.05)\end{array}$ & $\begin{array}{l}-0.08 \\
(0.11)\end{array}$ & $\begin{array}{l}-0.02 \\
(0.08)\end{array}$ & $\begin{array}{c}0.10 \\
(0.10)\end{array}$ & $\begin{array}{c}0.15 \\
(0.08)\end{array}$ & $\begin{array}{c}0.19 \\
(0.06)\end{array}$ \\
\hline Core CPI & $\begin{array}{c}0.67 \\
(0.05)\end{array}$ & $\begin{array}{c}1.57 \\
(0.10)\end{array}$ & $\begin{array}{c}1.17 \\
(0.08)\end{array}$ & $\begin{array}{c}1.49 \\
(0.10)\end{array}$ & $\begin{array}{c}1.22 \\
(0.08)\end{array}$ & $\begin{array}{c}0.78 \\
(0.06)\end{array}$ \\
\hline PPI & $\begin{array}{c}0.11 \\
(0.05)\end{array}$ & $\begin{array}{c}0.28 \\
(0.09)\end{array}$ & $\begin{array}{c}0.20 \\
(0.07)\end{array}$ & $\begin{array}{c}0.22 \\
(0.08)\end{array}$ & $\begin{array}{c}0.26 \\
(0.06)\end{array}$ & $\begin{array}{c}0.18 \\
(0.04)\end{array}$ \\
\hline Core PPI & $\begin{array}{c}0.63 \\
(0.07)\end{array}$ & $\begin{array}{c}1.07 \\
(0.10)\end{array}$ & $\begin{array}{c}0.80 \\
(0.08)\end{array}$ & $\begin{array}{c}1.06 \\
(0.09)\end{array}$ & $\begin{array}{c}0.91 \\
(0.07)\end{array}$ & $\begin{array}{c}0.70 \\
(0.05)\end{array}$ \\
\hline Hourly earnings & $\begin{array}{c}0.88 \\
(0.12)\end{array}$ & $\begin{array}{c}1.84 \\
(0.17)\end{array}$ & $\begin{array}{c}1.44 \\
(0.14)\end{array}$ & $\begin{array}{c}2.02 \\
(0.17)\end{array}$ & $\begin{array}{c}1.61 \\
(0.13)\end{array}$ & $\begin{array}{c}0.97 \\
(0.09)\end{array}$ \\
\hline Unemp & $\begin{array}{l}-1.23 \\
(0.11)\end{array}$ & $\begin{array}{l}-2.04 \\
(0.18)\end{array}$ & $\begin{array}{l}-1.64 \\
(0.14)\end{array}$ & $\begin{array}{l}-1.70 \\
(0.15)\end{array}$ & $\begin{array}{c}-1.18 \\
(0.12)\end{array}$ & $\begin{array}{l}-0.68 \\
(0.08)\end{array}$ \\
\hline FOMC & $\begin{array}{c}0.57 \\
(0.04)\end{array}$ & $\begin{array}{c}0.42 \\
(0.04)\end{array}$ & $\begin{array}{c}0.28 \\
(0.04)\end{array}$ & $\begin{array}{c}0.14 \\
(0.04)\end{array}$ & $\begin{array}{c}0.03 \\
(0.02)\end{array}$ & $\begin{array}{l}-0.02 \\
(0.01)\end{array}$ \\
\hline$f_{C P I, t}$ & $\begin{array}{c}1.10 \\
(0.05)\end{array}$ & $\begin{array}{c}2.63 \\
(0.09)\end{array}$ & $\begin{array}{c}2.08 \\
(0.07)\end{array}$ & $\begin{array}{c}2.63 \\
(0.08)\end{array}$ & $\begin{array}{c}2.10 \\
(0.06)\end{array}$ & $\begin{array}{c}1.46 \\
(0.05)\end{array}$ \\
\hline$f_{\text {Durable }, t}$ & $\begin{array}{c}0.81 \\
(0.06)\end{array}$ & $\begin{array}{c}1.99 \\
(0.10)\end{array}$ & $\begin{array}{c}1.51 \\
(0.06)\end{array}$ & $\begin{array}{c}1.85 \\
(0.06)\end{array}$ & $\begin{array}{c}1.49 \\
(0.04)\end{array}$ & $\begin{array}{c}0.98 \\
(0.03)\end{array}$ \\
\hline$f_{\text {EmpCost } t}$ & $\begin{array}{c}0.81 \\
(0.13)\end{array}$ & $\begin{array}{c}2.52 \\
(0.25)\end{array}$ & $\begin{array}{c}2.09 \\
(0.19)\end{array}$ & $\begin{array}{c}2.70 \\
(0.27)\end{array}$ & $\begin{array}{c}2.10 \\
(0.23)\end{array}$ & $\begin{array}{c}1.45 \\
(0.16)\end{array}$ \\
\hline$f_{G D P, t}$ & $\begin{array}{c}1.47 \\
(0.31)\end{array}$ & $\begin{array}{c}3.08 \\
(0.23)\end{array}$ & $\begin{array}{c}2.23 \\
(0.19)\end{array}$ & $\begin{array}{c}2.73 \\
(0.19)\end{array}$ & $\begin{array}{c}2.18 \\
(0.14)\end{array}$ & $\begin{array}{c}1.35 \\
(0.08)\end{array}$ \\
\hline$f_{\text {Claims }, t}$ & $\begin{array}{c}0.64 \\
(0.03)\end{array}$ & $\begin{array}{c}1.53 \\
(0.05)\end{array}$ & $\begin{array}{c}1.14 \\
(0.03)\end{array}$ & $\begin{array}{c}1.45 \\
(0.03)\end{array}$ & $\begin{array}{c}1.19 \\
(0.02)\end{array}$ & $\begin{array}{c}0.80 \\
(0.02)\end{array}$ \\
\hline$f_{\text {NonFarm }, t}$ & $\begin{array}{c}2.57 \\
(0.11)\end{array}$ & $\begin{array}{c}5.68 \\
(0.17)\end{array}$ & $\begin{array}{c}4.42 \\
(0.13)\end{array}$ & $\begin{array}{c}5.50 \\
(0.13)\end{array}$ & $\begin{array}{c}4.23 \\
(0.10)\end{array}$ & $\begin{array}{c}2.67 \\
(0.08)\end{array}$ \\
\hline$f_{P P I, t}$ & $\begin{array}{c}1.28 \\
(0.09)\end{array}$ & $\begin{array}{c}2.44 \\
(0.10)\end{array}$ & $\begin{array}{c}1.97 \\
(0.07)\end{array}$ & $\begin{array}{c}2.37 \\
(0.09)\end{array}$ & $\begin{array}{c}1.95 \\
(0.08)\end{array}$ & $\begin{array}{c}1.35 \\
(0.05)\end{array}$ \\
\hline$f_{\text {Retail }, t}$ & $\begin{array}{c}1.50 \\
(0.15)\end{array}$ & $\begin{array}{c}2.94 \\
(0.17)\end{array}$ & $\begin{array}{c}2.28 \\
(0.10)\end{array}$ & $\begin{array}{c}2.52 \\
(0.10)\end{array}$ & $\begin{array}{c}1.92 \\
(0.07)\end{array}$ & $\begin{array}{c}1.18 \\
(0.05)\end{array}$ \\
\hline$f_{F O M C, t}$ & $\begin{array}{c}2.19 \\
(0.18)\end{array}$ & $\begin{array}{c}6.17 \\
(0.33)\end{array}$ & $\begin{array}{c}4.58 \\
(0.24)\end{array}$ & $\begin{array}{c}5.11 \\
(0.32)\end{array}$ & $\begin{array}{c}3.58 \\
(0.22)\end{array}$ & $\begin{array}{c}2.02 \\
(0.15)\end{array}$ \\
\hline$R^{2}$ no factor & 0.40 & 0.36 & 0.37 & 0.36 & 0.34 & 0.30 \\
\hline$R^{2}$ release factors & 0.73 & 0.93 & 0.94 & 0.98 & 0.96 & 0.88 \\
\hline
\end{tabular}

Notes: Standard errors are in parentheses. Macroeconomic surprises are normalized by their respective standard deviations. Monetary policy surprises are in basis points. The $R^{2}$ values reported are those for announcement day yields using (i) only headline surprises, (ii) headline surprises and latent factors. The sample is 1992-2018 for macroeconomic announcements, 1992-2007 for monetary policy surprises. 
where $y_{t}$ is a scalar log return or yield change, $s_{t}$ is the scalar observed surprise, $s_{t}^{*}$ is the true headline surprise, $d_{t}$ is a dummy that is 1 on an announcement day and 0 otherwise, $f_{t}$ is an i.i.d. $N(0,1)$ latent variable, and $\varepsilon_{t}$ and $\eta_{t}$ are processes measuring noise in yields and measurement error of the headline surprise. We assume that $s_{t}^{*}, \varepsilon_{t}$, and $\eta_{t}$ are i.i.d., mutually uncorrelated, have mean zero, and variances $\sigma_{*}^{2}, \sigma_{\varepsilon}^{2}$, and $\sigma_{\eta}^{2}$, respectively. To estimate $\beta$, the parameter of interest in event studies, using OLS and identification through heteroskedasticity, we need the variance-covariance matrices for event $\left(\Omega^{E}\right)$ and nonevent $\left(\Omega^{N E}\right)$ windows:

$$
\Omega^{E}=\left(\begin{array}{cc}
\beta^{2} \sigma_{*}^{2}+\gamma^{2}+\sigma_{\varepsilon}^{2} & \beta \sigma_{*}^{2} \\
\cdot & \sigma_{*}^{2}+\sigma_{\eta}^{2}
\end{array}\right), \quad \Omega^{N E}=\left(\begin{array}{cc}
\sigma_{\varepsilon}^{2} & 0 \\
0 & 0
\end{array}\right) .
$$

In this general model, the OLS estimate for $\beta$ is

$$
\hat{\beta}^{O L S}=\frac{\left[\hat{\Omega}^{E}\right]_{1,2}}{\left[\hat{\Omega}^{E}\right]_{2,2}}
$$

and the identification through heteroskedasticity estimate of $\beta$ is

$$
\hat{\beta}^{H E T}=\frac{\left[\hat{\Omega}^{E}\right]_{1,1}-\left[\hat{\Omega}^{N E}\right]_{1,1}}{\left[\hat{\Omega}^{E}\right]_{1,2}} .
$$

This general model collapses to a model with no latent factor if $\gamma=0$ and it collapses to the no measurement error case (the case we argue for in this paper) when $\sigma_{\eta}^{2}=0$. In the general model, as shown in online Appendix Section $\mathrm{C}$, the probability limits of the two estimators are

$$
\hat{\beta}^{O L S} \rightarrow \beta\left(1-\frac{\sigma_{\eta}^{2}}{\sigma_{*}^{2}+\sigma_{\eta}^{2}}\right)
$$

and

$$
\hat{\beta}^{H E T} \rightarrow \beta\left(1+\frac{\gamma^{2}}{\beta^{2} \sigma_{*}^{2}}\right)
$$

If there is neither a latent factor $(\gamma=0)$ nor measurement error in the surprise $\left(\sigma_{\eta}^{2}=0\right)$, the OLS and heteroskedasticity based estimators both uncover the true $\beta$ and should coincide. However, as Tables 1 and 2 show, these are significantly different from each other, implying that this is not the relevant case.

With a latent factor, the heteroskedasticity-based estimator is biased away from zero. Note that the term $\gamma^{2} /\left(\beta^{2} \sigma_{*}^{2}\right)$ is proportional to the variance share of the latent factor in the event window changes of yields. As the relative variance share of the latent factor increases (non-headline news carries more information affecting 
yields), the bias of the heteroskedasticity-based estimator for the headline effect increases. ${ }^{9}$

With measurement error, the OLS estimate will be biased toward zero because of classical attenuation bias. This bias is proportional to the share of measurement error in total variance of the observed surprise, $\sigma_{\eta}^{2} /\left(\sigma_{*}^{2}+\sigma_{\eta}^{2}\right)$.

Except for the case where there is no latent factor and no measurement error in the surprise, the probability limit of the heteroskedasticity-based estimator will always be larger than the OLS estimate in absolute value, as we find in the data. However, this could be because of a latent factor $(\gamma \neq 0)$, or measurement error $\left(\sigma_{\eta}^{2} \neq 0\right)$, or both. It is this observational equivalence that makes it impossible to judge whether OLS is consistent by only looking at the difference between the OLS and heteroskedasticity-based estimates. ${ }^{10}$ One has to take a stance on the extent of measurement error. Given the observed difference between the two estimators, that stance is consequently also on the presence of unobserved surprises and the consistency of the heteroskedasticity-based estimator.

We argue that measurement error in survey-based surprises is negligible, so $\sigma_{\eta}^{2} \approx 0$, and therefore $\hat{\beta}^{O L S}$ is consistent, whereas $\hat{\beta}^{H E T}$ is not. We shall do this in Subsection IIIB, by bringing in data from economic derivatives to show that measurement error in the survey-based surprises is likely to be negligible for event studies. As further corroborating evidence, the bias term for heteroskedasticity-based identification when there is a latent factor, discussed above, shows that the difference between $\hat{\beta}^{H E T}$ and $\hat{\beta}^{O L S}$ should be larger when $|\gamma|$ is larger, that is when events have larger non-headline components. To examine this, in Subsection IIIC, we shall compare monetary policy announcements with and without accompanying statements. We will show that heteroskedasticity-based estimates are closer to the OLS counterparts on days without monetary policy statements compared to the days with statements.

\section{B. Quality of Survey Expectations}

The surveys used in event studies are those of news releases that are to take place very soon, no longer than a week after the time of the survey. And the "event" is the release of information on something that has already taken place. Hence, these expectations are not necessarily subject to the anomalies often reported in analysis of long-term expectations (Fuhrer 2017). ${ }^{11}$

Nonetheless, three areas of concern remain: (i) the survey expectation may be stale, i.e., there may be incoming news between a respondent's reporting of her expectation and the releases, which change her expectations, (ii) respondents may not have sufficient skin in the game, and (iii) respondents may have an incentive to be right in the extreme case, not on average, therefore reporting numbers closer to the tails rather than their true expectations, especially if their predictions are not

\footnotetext{
${ }^{9}$ As the variance of the latent factor $\sigma_{f}^{2}$ is normalized to unity, $\gamma^{2}$ itself is the measure of variance due to the latent factor.

${ }^{10}$ It is also the reason why measurement error in the observable and a latent factor cannot simultaneously be estimated.

${ }^{11}$ Notwithstanding these anomalies, Ang, Bekaert, and Wei (2007) show that survey expectations remain the best forecasts among many alternatives, even at longer horizons.
} 
anonymous. We argue that while these concerns sound relevant, in practice survey expectations work remarkably well and are not subject to large measurement errors.

To do so, we compare the survey-based expectations to timely market-based expectations. The latter data come from Gürkaynak and Wolfers (2007), who analyze the market for Economic Derivatives. This was a market, now defunct, where Deutsche Bank and Goldman Sachs allowed trades of binary options on news releases about half an hour before the release itself. ${ }^{12}$ Market-based expectations of data releases are not subject to any of the potential measurement error problems that survey-based ones might be. The market operates minutes before the data release, hence there is no scope for staleness; the traders do have skin in the game as they bet on their expectations; and since the market returns are anonymous they have no special incentive to get low probability events right.

We construct market- and survey-based expectations and news surprises based on these and directly test whether there is measurement error in survey-based expectations by comparing the market responses to the two surprise measures. If there is sizable measurement error in survey-based surprises, event study coefficients based on these should be significantly smaller than coefficients based on Economic Derivatives-based surprises, which are not subject to measurement error.

We run SUR regressions for the four releases covered by Economic Derivatives (Nonfarm payrolls, NAPM, Retail Sales ex-Autos, and Initial Claims) of the form

$$
\begin{aligned}
& y_{t}=\sum_{i=1}^{4} \theta_{i}^{s} S_{i t}^{\text {SURVEY }}+\varepsilon_{t}, \\
& y_{t}=\sum_{i=1}^{4} \theta_{i}^{m} S_{i t}^{\text {ECON-DERIV }}+\varepsilon_{t},
\end{aligned}
$$

where $S_{i t}^{S U R V E Y}$ and $S_{i t}^{E C O N-D E R I V}$ are surprises where expectations are measured using surveys and Economic Derivatives, respectively. Measurement error in survey expectations will lead to smaller $\theta^{s}$ compared to $\theta^{m}$. Table 5 reports the results as well as the joint test of the hypothesis that $\theta_{i}^{s}=\theta_{i}^{m}$ for all $i$. It is striking that while all estimated $\theta_{i}^{s} \mathrm{~s}$ are somewhat smaller than corresponding $\theta_{i}^{m} \mathrm{~s}$ (consistent with minor classical measurement error) the differences in point estimates are small and in no cases individually or jointly statistically significant. ${ }^{13}$ Thus we conclude that survey expectations capture market expectations extremely well. Even if one attributes all of the difference between point estimates to measurement error, the differences are on the order of 5 to 15 percent, an order of magnitude smaller than the gap between OLS and heteroskedasticity-based estimates shown in Tables 1 and 2. These substantial differences cannot be predominantly due to measurement error in surveys and resulting attenuation bias in the coefficients.

\footnotetext{
${ }^{12}$ These call options paid off if the release came in at or above the buyer's strike price. Gürkaynak and Wolfers (2007) describe the market and these options, as well as the methodology to use them to construct risk neutral probability density functions of market perceived data release outcomes.

${ }^{13}$ In his discussion of Gürkaynak and Wolfers (2007), Carroll (2007) notes how the survey- and market-based expectations are remarkably similar to each other in terms of first moments. This is consistent with what we find here but the similarity is actually stronger: for almost every single event, the market- and survey-based expectations are very close to each other.
} 
Table 5-Seemingly Unrelated Regression (SUR) Results For ED1, ED4, AND ON-THE-RUN 2-, 5-, 10-, AND 30-YEAR YIELDS

\begin{tabular}{|c|c|c|c|c|c|c|c|}
\hline & Non-farm & Initial claims & NAPM & Retail & Obs. & $R^{2}$ & $p$-value $\left(\chi^{2}\right)$ \\
\hline \multicolumn{8}{|l|}{$\overline{\text { ED1 }}$} \\
\hline Auction & $\begin{array}{c}1.40 \\
(0.19)\end{array}$ & $\begin{array}{l}-0.12 \\
(0.13)\end{array}$ & $\begin{array}{c}0.05 \\
(0.12)\end{array}$ & $\begin{array}{c}0.19 \\
(0.19)\end{array}$ & 152 & 0.31 & 0.82 \\
\hline Survey & $\begin{array}{c}1.33 \\
(0.20)\end{array}$ & $\begin{array}{c}-0.11 \\
(0.13)\end{array}$ & $\begin{array}{c}0.04 \\
(0.12)\end{array}$ & $\begin{array}{c}0.17 \\
(0.19)\end{array}$ & 152 & 0.28 & \\
\hline \multicolumn{8}{|l|}{ ED4 } \\
\hline Auction & $\begin{array}{c}6.99 \\
(0.63)\end{array}$ & $\begin{array}{l}-0.53 \\
(0.44)\end{array}$ & $\begin{array}{c}0.43 \\
(0.43)\end{array}$ & $\begin{array}{c}0.40 \\
(0.65)\end{array}$ & 153 & 0.48 & 0.87 \\
\hline Survey & $\begin{array}{c}6.75 \\
(0.66)\end{array}$ & $\begin{array}{l}-0.51 \\
(0.46)\end{array}$ & $\begin{array}{c}0.37 \\
(0.45)\end{array}$ & $\begin{array}{c}0.38 \\
(0.68)\end{array}$ & 153 & 0.45 & \\
\hline \multicolumn{8}{|l|}{ Two-year } \\
\hline Auction & $\begin{array}{c}4.72 \\
(0.49)\end{array}$ & $\begin{array}{l}-0.38 \\
(0.34)\end{array}$ & $\begin{array}{c}0.36 \\
(0.32)\end{array}$ & $\begin{array}{c}0.35 \\
(0.50)\end{array}$ & 153 & 0.42 & 0.87 \\
\hline Survey & $\begin{array}{c}4.54 \\
(0.52)\end{array}$ & $\begin{array}{l}-0.36 \\
(0.36)\end{array}$ & $\begin{array}{c}0.30 \\
(0.34)\end{array}$ & $\begin{array}{c}0.33 \\
(0.53)\end{array}$ & 153 & 0.38 & \\
\hline \multicolumn{8}{|l|}{ Five-year } \\
\hline Auction & $\begin{array}{c}5.62 \\
(0.54)\end{array}$ & $\begin{array}{l}-0.47 \\
(0.37)\end{array}$ & $\begin{array}{c}0.54 \\
(0.37)\end{array}$ & $\begin{array}{c}0.49 \\
(0.56)\end{array}$ & 153 & 0.45 & 0.78 \\
\hline Survey & $\begin{array}{c}5.39 \\
(0.57)\end{array}$ & $\begin{array}{l}-0.44 \\
(0.40)\end{array}$ & $\begin{array}{c}0.45 \\
(0.39)\end{array}$ & $\begin{array}{c}0.45 \\
(0.39)\end{array}$ & 153 & 0.41 & \\
\hline \multicolumn{8}{|l|}{ Ten-year } \\
\hline Auction & $\begin{array}{c}4.37 \\
(0.45)\end{array}$ & $\begin{array}{l}-0.37 \\
(0.31)\end{array}$ & $\begin{array}{c}0.42 \\
(0.30)\end{array}$ & $\begin{array}{c}0.41 \\
(0.46)\end{array}$ & 153 & 0.43 & 0.88 \\
\hline Survey & $\begin{array}{c}4.22 \\
(0.47)\end{array}$ & $\begin{array}{l}-0.35 \\
(0.33)\end{array}$ & $\begin{array}{c}0.36 \\
(0.32)\end{array}$ & $\begin{array}{c}0.38 \\
(0.48)\end{array}$ & 153 & 0.4 & \\
\hline
\end{tabular}

Notes: Auction are the coefficients for the market based surprises and Survey are MMS/Action Economics survey-based surprise coefficients. Standard errors are in parentheses; $p$-value is the joint test statistic of equality between auction and survey estimates. The sample is from October 2002 to July 2005.

\section{Comparison of OLS and Heteroskedasticity-Based Estimates}

A well-studied and well-understood case of multidimensional data release is that of FOMC announcements, which contain both the interest rate decision and an accompanying statement providing information on the future course of interest rates. This is a case we will return to in more detail but here we will exploit the fact that FOMC releases did not always contain statements. Until 1994, the FOMC did not issue statements and until 1999 statements were only issued when the policy rate was changed.

Under the measurement error model, the difference between OLS and heteroskedasticity-based estimators should not depend on the presence of an accompanying statement. If on the other hand, as we suggest, heteroskedasticity-based identification provides the asset price response to the whole "event" rather than just the headline, the difference between the two measures should be larger when the non-headline component is more important, i.e., $\gamma$ is larger. Increasing the importance of non-headline news is exactly what the FOMC did when it began to issue statements. So, if our conjecture is correct, the coefficient estimates of the impact of FOMC announcements on yields measured by OLS and heteroskedasticity-based 
Table 6-OLS and Heteroskedasticity-Based Results for the Days with and without Monetary Policy Statements

\begin{tabular}{lcccccc}
\hline \hline & ED1 & ED4 & 2-year & 5-year & 10-year & 30-year \\
\hline FOMC full sample & & & & & & \\
OLS & 0.57 & 0.44 & 0.28 & 0.14 & 0.03 & -0.02 \\
& $(0.07)$ & $(0.1)$ & $(0.09)$ & $(0.07)$ & $(0.04)$ & $(0.02)$ \\
ID HET & 0.85 & 1.93 & 1.46 & 3.11 & 6.69 & -4.09 \\
& $(0.09)$ & $(0.53)$ & $(0.47)$ & $(1.55)$ & $(8.69)$ & $(5.85)$ \\
FOMC no statement & & & & & & \\
OLS & 0.76 & 0.84 & 0.55 & 0.25 & 0.09 & 0.04 \\
& $(0.20)$ & $(0.29)$ & $(0.18)$ & $(0.15)$ & $(0.09)$ & $(0.04)$ \\
ID HET & 0.88 & 1.02 & 0.65 & 0.05 & -0.13 & -0.28 \\
& $(0.11)$ & $(0.16)$ & $(0.09)$ & $(0.50)$ & $(0.54)$ & $(0.64)$ \\
FOMC statement & & & & & & \\
OLS & 0.55 & 0.40 & 0.25 & 0.13 & 0.03 & -0.02 \\
ID HET & $(0.08)$ & $(0.09)$ & $(0.09)$ & $(0.07)$ & $(0.05)$ & $(0.02)$ \\
& 0.85 & 2.11 & 1.61 & 3.56 & 8.45 & -3.56 \\
Equivalence test for statement and non-statement days & 0.97 & 1.46 & 1.47 & 0.70 & 0.61 & $(4.30)$ \\
OLS & $(0.10)$ & $(0.65)$ & $(0.60)$ & $(1.89)$ & $(13.28)$ & 1.36 \\
ID HET & 0.18 & -1.61 & -1.57 & -1.79 & -0.65 & 0.75 \\
\hline
\end{tabular}

Note: Standard errors are in parentheses.

estimators should be closer for a sample of events consisting of policy actions only, than for a sample consisting of announcements that also have statements providing information on the policy path.

For monetary policy surprises, as before, we follow the standard procedure and use federal funds futures-based surprises as suggested by Kuttner (2001). Table 6 shows that when statements do not accompany the policy rate decision, the OLS and heteroskedasticity-based estimates of the asset price reactions are quite similar, though the OLS estimates are smaller due to market participants' inference of information even in the absence of formal statements. But for the sample that includes statements the heteroskedasticity-based estimator yields a reaction coefficient that is two to 400 times larger than the OLS estimator.

What is striking here is not that OLS coefficients are a little smaller and statistically less significant in the latter sample. This is due to the dearth of policy action surprises in the twenty-first century, when policy actions were usually signaled ahead of the FOMC meeting date (Swanson 2006). What is noteworthy is the increase in the spread between OLS and heteroskedasticity-based estimators, and the fact that the spread becomes significantly more pronounced as maturity increases. The last row of the table shows that the increase in the difference is statistically significant. This is exactly what one would expect to find based on our conjecture: the presence of a statement will increase the distance between OLS and heteroskedasticity-based estimates for all maturities but as the statement is more informative for longer maturities ${ }^{14}$ the heteroskedasticity-based estimator will find even larger coefficients for those maturities.

\footnotetext{
${ }^{14}$ The literature, described in the next section, finds that quantifying the statement can explain the movement in longer maturities, whereas short maturities are more responsive to the immediate policy action.
} 
TABLE 7-FOMC COMMENTARY

\begin{tabular}{|c|c|c|}
\hline Date & Factor & Commentary \\
\hline August 13, 2002 & 4.49 & $\begin{array}{l}\text { Statement announces balance of risks has shifted from neutral to economic } \\
\text { weakness. }\end{array}$ \\
\hline January 28, 2004 & 4.40 & $\begin{array}{l}\text { Statement drops commitment to keep policy unchanged for "considerable } \\
\text { period," bringing forward expectations of future tightenings. }\end{array}$ \\
\hline July 6, 1995 & -4.05 & $\begin{array}{l}\text { First easing after long (17-month) series of tightenings raises expectations of } \\
\text { further easings; statement notes that inflationary pressures have receded. }\end{array}$ \\
\hline April 9, 1992 & -3.75 & $\begin{array}{l}\text { Federal Reserve officials were worried that the weak growth in money supply } \\
\text { could slow the recovery. (New York Times, June } 24,1992)\end{array}$ \\
\hline May 17, 1994 & -3.39 & $\begin{array}{l}\text { Fed's move is perceived as a "combative response to markets that for weeks } \\
\text { have been demanding convincing evidence... that it was doing enough to rein in } \\
\text { economic growth and dampen inflation expectations." (New York Times, May 18, } \\
\text { 1994) }\end{array}$ \\
\hline
\end{tabular}

Notes: Table shows the 5 largest (absolute) values of the latent factor monetary policy announcements with associated dates and the summary of the statements. January 28, 2004, August 13, 2002, July 6, 1995 commentary are from Gürkaynak, Sack, and Swanson (2005).

Thus, by studying the FOMC announcement dates, we conclude that the heteroskedasticity-based estimator provides a convolution of the asset price responses to the headline and non-headline components of news, whereas our partial observability-based Kalman filtering methodology provides asset price responses to headline news and the latent non-headline news component separately. An additional benefit is that this method estimates the latent component directly, and allows it to be given an economic interpretation.

It can be shown, as we do in online Appendix Section C, that the heteroskedasticity-based estimator is essentially the sum of the OLS response to the observables and the response to the latent variable that can be extracted from the residuals. The method that we developed does this efficiently, in one step.

\section{Interpreting the Latent Factor}

So far we have focused on the relationship between the heteroskedasticity-based, OLS and Kalman filter-based estimators and showed that the discrepancy between the two is better understood as arising from the presence of unobserved surprises in releases rather than measurement error in observed surprises. We also showed that a single factor estimated using the Kalman filter along with observable headline surprises is sufficient to explain the variation in asset prices around macroeconomic news events. In this subsection, we closely examine the economic interpretation of that latent factor.

Table 7 lists the five largest readings of the latent factor in FOMC announcement windows and shows that based on the comments in the financial press, these are indeed days of well-known "statement surprises." Monetary policy statement surprises are well understood and it is reassuring that the latent factor we extract behaves as expected. Non-headline surprises in other macroeconomic data releases are much less well understood, not only in the academic literature but also in the financial press. Thus, the financial press reports of non-headline items are often boilerplate, listing the numbers without much commentary, so doing the same exercise 


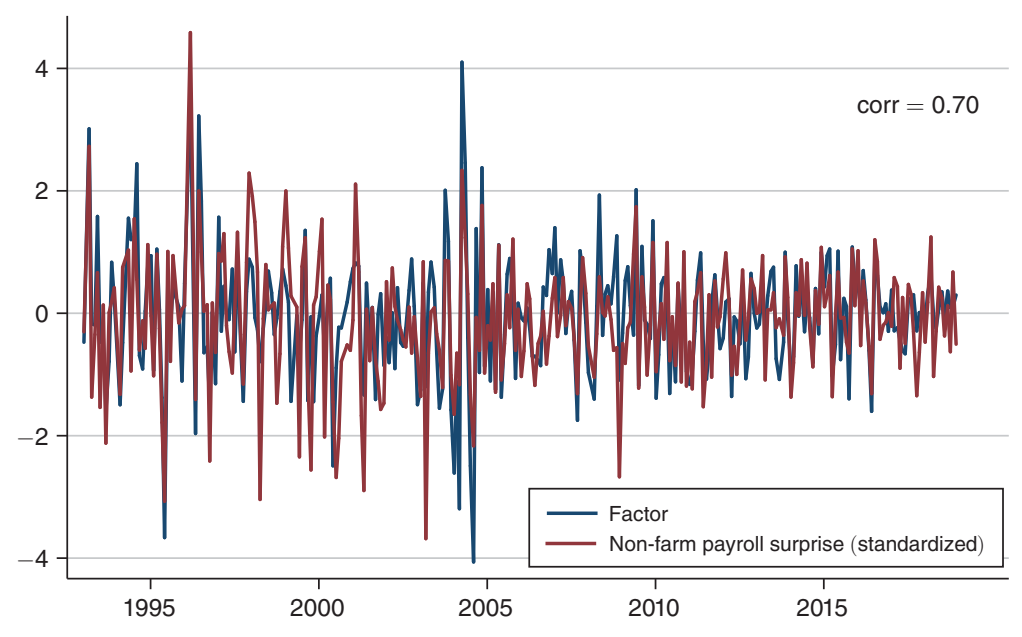

FIGURE 3

Note: Shows the time series of nonfarm payrolls surprise and the latent factor estimated around employment report days treating nonfarm payrolls surprise as unobservable.

for macroeconomic data releases is not possible. We therefore do the next best thing and create pseudo-unobservable surprises.

To verify that our method indeed picks up unsurveyed news in data releases we take the observable surprises in the employment report-nonfarm payrolls, unemployment rate, and hourly earnings - and drop the nonfarm payrolls surprise from the data, treating it as if this component of the employment report is not surveyed and hence its surprise is unobservable to the econometrician. ${ }^{15}$ We then look at the correlation between the latent factor we extract on employment report release days and the surprise that we have excluded from the data. Figure 3 shows the results of the exercise. The correlation between the nonfarm payrolls surprise and the latent factor extracted from the factor model is striking. The estimated latent factor indeed tracks the surprise as measured by the survey. The correlation is not perfect because the truly unobserved surprises are also being picked up by the factor, but as the nonfarm payrolls surprise has a large variance share, this is closely tracked by the estimated latent factor.

We have shown that the financial market responses to news announcements depend on surprises, some of which are observed by both market participants and the econometrician, and some of which are observed by market participants but not directly by the econometrician. These responses to both kinds of news may perhaps be due to behavioral finance effects; market participants extracting information on an underlying state of the economy from the releases; or in the case of FOMC announcements, non-overlapping information sets between FOMC and the public. These are issues that go to the heart of financial and macroeconomic research that

\footnotetext{
${ }^{15}$ Doing this for the other two observed surprises produces similar results but since nonfarm payrolls surprises elicit the largest yield curve responses, visually this case is easier to present.
} 
can be studied better now that we have a complete understanding of what the effects are. We emphasize that understanding why the markets react the way they do is a distinct question from what the reaction is, and that answering the latter question requires addressing the complication arising from the presence of news not observed by the econometrician, using methodology proposed here. That is, the methodology we propose is invariant to the drivers of effects of surprises, which is a separate line of research.

We next turn to understanding why a single factor across releases is sufficient and to further analysis of that factor.

Why Is a Single Factor Sufficient?-One of the most interesting findings of this paper is that a single latent factor is sufficient to capture almost all of the non-headline variation in yields around news releases. This would have been surprising if a single factor per release were sufficient, e.g., all the non-surveyed/unobservable information in the employment report being captured by a single latent factor, but it is very surprising that a single factor across releases is sufficient. The model with a single latent factor is literally misspecified in that it ignores differences in variance across releases, as evidenced by the fact that the latent variable spikes most often on employment report days (not shown for brevity). However this does not prevent the single factor from capturing almost all non-headline variation in yields around announcements. This is because individual latent factors are simply different scalings of the common factor. In Figure 4 we show the correlation of the common factor with the individual latent factors and show that there is almost perfect correlation in most cases. 16

Not only is it the case that all individual latent factors elicit the same response from the yield curve, but observable surprises also elicit this response. The latent factor has a hump-shaped effect on the yield curve, which is very similar to the hump-shaped effect of observed macroeconomic news surprises on the yield curve documented in Table 1. Both latent and observed news surprises have peak effects at a maturity of around one to two years. They also both have a sizable effect on long-term yields. Given that all news, observed or unobserved, have the same hump-shaped effect on the yield curve, one might suppose that we could have treated the headline news as unobservable as well and only extracted a single latent factor, without compromising the fit. Table 8 shows the result of this exercise, and the fit is indeed about the same. Note that mechanically these are the heteroskedasticity-based estimator effects but our methodology allows measuring $R^{2}$, and shows that the fit remains about the same when all news are treated as unobservable. This is closely related to another approach considered by Rigobon and Sack (2008), which is simply to measure the news surprise by the first principal component of $y_{t}$ in announcement windows alone.

This finding reinforces our argument that news releases are multidimensional and unobserved/unsurveyed surprises also elicit asset price responses just like headline

\footnotetext{
${ }^{16}$ While some panels, such as the employment report, show an almost exact match, others, such as initial claims, depict two sets of points, one along the 45-degree line and one not. The latter are less important releases that do not dominate the change in the variance when there are multiple releases in the same window. When they are the only release in that window the common factor and the individual factor line up exactly but days with other releases in the same window produce the diffuse set of points.
} 

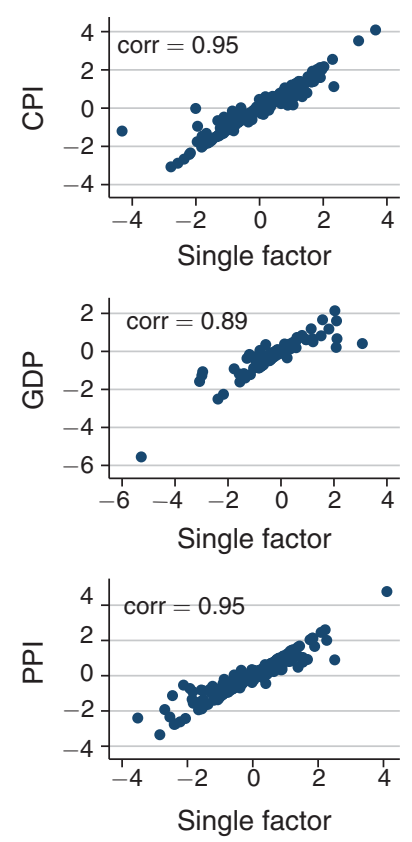
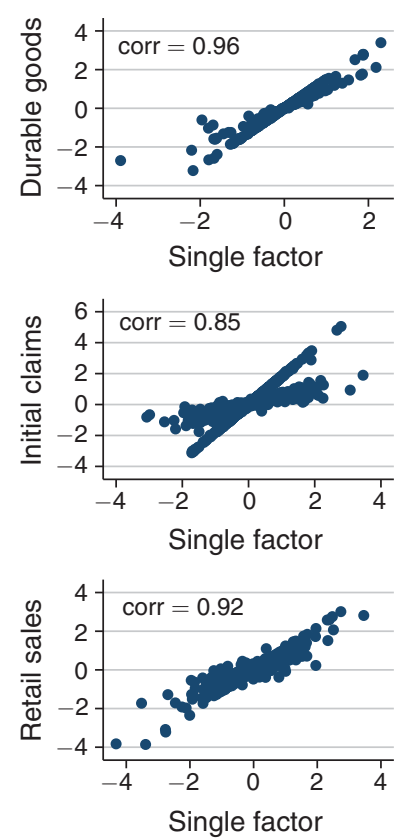
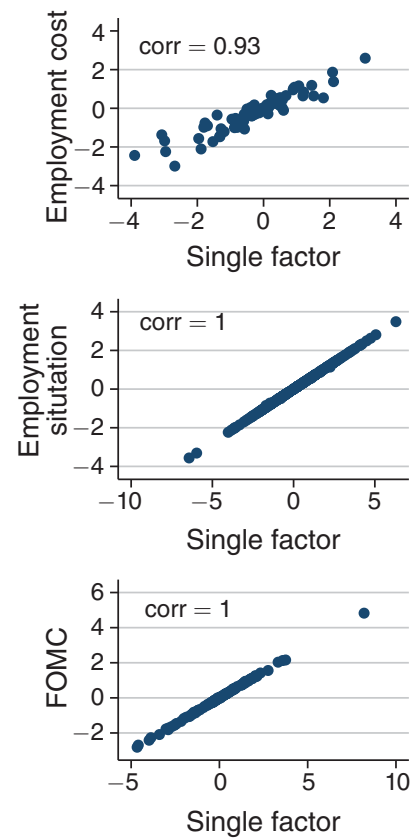

FIGURE 4

Note: Scatter plot of the single factor and individual release factors around relevant event windows.

Table 8-Estimates of Equation (7) When Headline and FOMC Surprises ARe UnOBSERVABLE

\begin{tabular}{lcccccc}
\hline \hline & ED1 & ED4 & 2-year & 5-year & 10-year & 30-year \\
\hline Factor & 1.90 & 3.99 & 3.09 & 3.70 & 2.83 & 1.78 \\
& $(0.06)$ & $(0.08)$ & $(0.06)$ & $(0.07)$ & $(0.05)$ & $(0.03)$ \\
$R^{2}$ & 0.62 & 0.92 & 0.94 & 0.98 & 0.95 & 0.85 \\
\hline
\end{tabular}

Notes: Standard errors are in parentheses. Responses of ED1, ED4, 2-year, 5-year, 10-year, and 30 -year yields are in basis points.

surprises. In all likelihood, every release has many unobserved surprises but since all of them elicit the same response in terms of the shape of the yield curve reaction, one latent factor per release is sufficient, as is one latent factor across releases. The hump shaped factor that we find is closely related to the level and slope components of the yield curve, with the bulk of it being level. ${ }^{[17}$ Thus, our procedure, as a by product of this application, finally lets us have a handle on what moves the yield curve, as captured predominantly by level, in event windows. It is driven by news.

It is important to emphasize the two separate findings here. The first is that observed and latent news both elicit hump-shaped responses from the yield curve, as shown by the regression coefficients. The second is that yield curve movements

\footnotetext{
${ }^{17}$ In unreported results, we extracted a level factor from yields in event windows and showed that we are able to explain about all of the variation in level in these windows with our method.
} 
in the event window are almost completely explained by those observed and latent factors, as shown by the $R^{2}$.

\section{E. Reaction to News: Rate Expectations or Term Premia}

We have shown that yield curve movements in event windows are driven by news. Yields, be they term rates or forwards, comprise expected future short rates and term premia. In this subsection, we assess how much of the yield curve response to news is changes in expected future short rates as opposed to changing term premia. Earlier work by Faust and Wright (2018) and Hördahl, Remolona, and Valente (2020) argued that the yield curve response to headline news partly represented changing term premia, but here we are considering both observed and latent news.

The approach that we adopt uses the term structure model of Adrian, Crump, and Moench (2013), which produces a decomposition of forward rates into expected short rates and term premia. ${ }^{18}$ We use daily data to find changes in expected short rates in term premia on event days and regress these (as well as the change in the forward rates themselves) on both observed surprises and unobserved surprises as measured by the latent factor that we estimate.

Figure 5 shows the effect of nonfarm payrolls surprise on forward rates, forward expected short rates, and forward term premia in its upper panel, and the effects of the employment report latent factor on the same variables in its lower panel. Before turning to a discussion of these results, it is useful to note that since all observables and all release specific latent variables have the same properties, it makes no difference whether we look at the employment report or any other release, or study release specific factors or the common factor. As we have shown before, they are all similarly informative and elicit the same responses (not shown again here for this decomposition) apart from scale factors.

Two main results emerge from Figure 5. The first is the striking similarity between the upper and lower panels of this figure. Observed and latent surprises elicit the same reaction from forward rates and their effects on forward expected short rates and forward term premia are similarly about identical. This is consistent with what we have shown so far. From the econometrician's perspective there are two types of surprises: observed and latent ones. From the market participants' perspective, there is no difference. They are all surprises that provide similar new information hence leading to similar updating of prices, similar changes in expected short rates and term premia.

The second result is that, for both observed and latent surprises, expected short rates react more and explain more of the changes in forward rates in response to news. ${ }^{19}$ In particular, the hump-shape is very pronounced in the expected future short rates' reaction. The reactions of expected future short rate to macroeconomic news surprises are similar to the impulse responses of short rates to macroeconomic shocks as measured by identified VARs (Bekaert, Cho, and Moreno 2010; Evans

\footnotetext{
${ }^{18}$ Using the Kim and Wright (2005) decomposition, which utilizes survey expectations of interest rates, to study the effects of observable and latent surprises on expected short rates and term premia produces qualitatively similar results.

${ }^{19}$ Note that each point in each line of Figure 5 comes from a separate regression, these are not impulse-responses.
} 

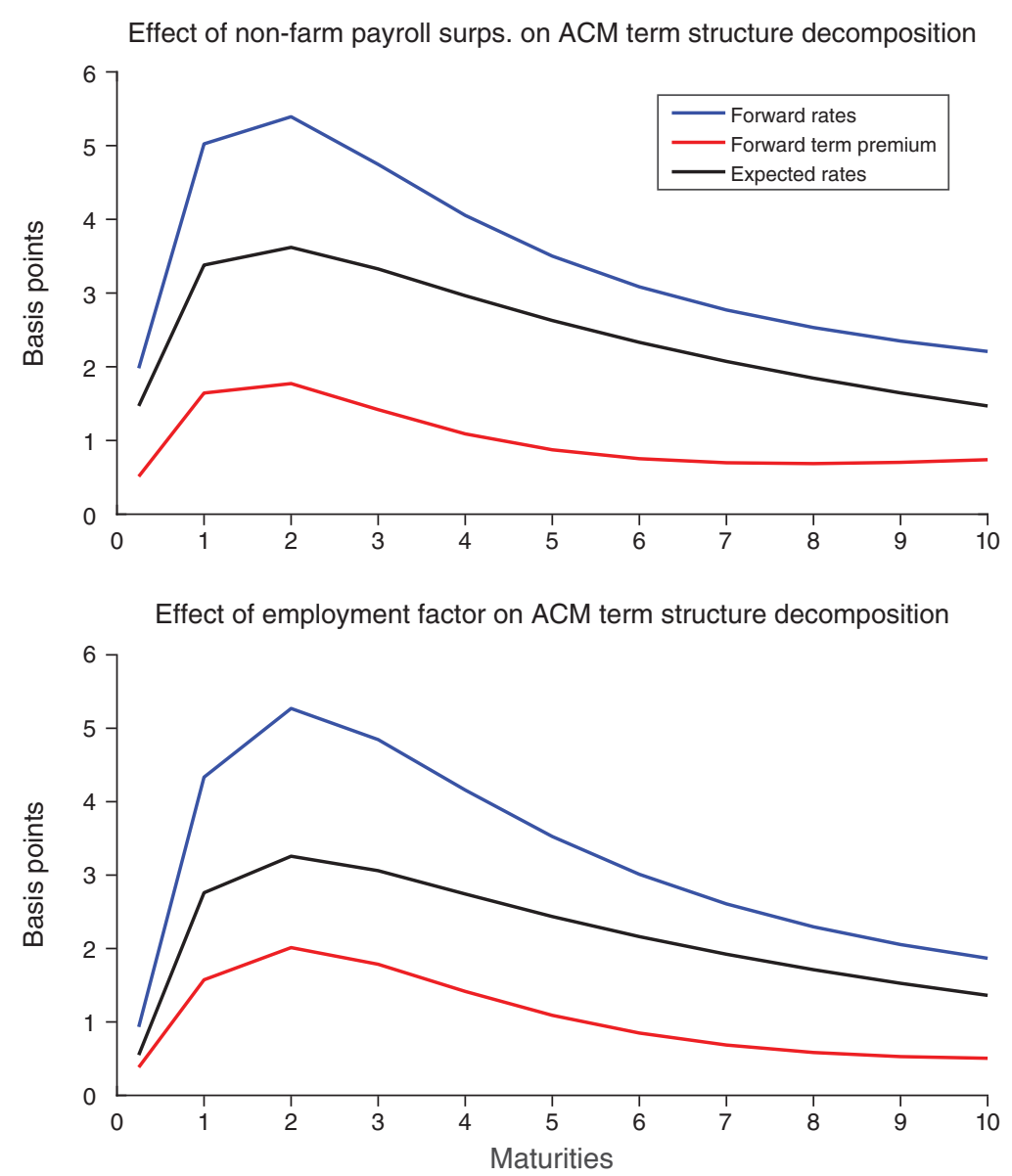

FIGURE 5

Notes: Response of the instantaneous forward rates and their components to the non-farm payroll headline surprise and the latent employment factor. The sample is 1992-2018. These are obtained by regression of changes in forward rates and their components onto the headline surprise (top panel) and latent employment factor (bottom panel). Confidence intervals are not reported here, but are in online Appendix G.

and Marshall 2007). This resemblance between market participants' updating of their beliefs about short rates in the future (reactions in the maturity dimension based on the event study) and the actual changes of short rates in response to macroeconomic shocks (reactions in the time dimension based on VARs) is noteworthy. The term premium response, while also exhibiting a hump, contributes less and has a flatter maturity profile.

\section{Extensions and Robustness}

There are several extensions and robustness checks that are in order. These are (i) studying the effects of observed and latent surprises on stock prices to make sure that the equivalence of the two types of surprises is not unique to fixed income returns, (ii) limiting the sample to the period before the financial crisis, so that estimates will 
not be affected by the short end being stuck at the ZLB, (iii) verifying that the latent factor is not just capturing a factor that is always driving yield curve movements and is unrelated to economic news, (iv) verifying that the Kalman filter, which uses all yields in extracting the latent factor, is not mechanically explaining long yields with themselves, (v) comparing the FOMC release factor to a well-studied statement factor derived using a different, two-step procedure, (vi) allowing for an unrestricted variance-covariance matrix for $\varepsilon_{t}$ in equation (7), and (vii) verifying that the results are robust to event window width specification. In this section we tackle these issues.

\section{A. Stock Returns and Data Releases}

We construct the latent factor for data releases from fixed income futures yields because this gives the sharpest identification. But if this latent factor is representing unmeasured news, it should affect other, non-fixed income asset prices as well. We therefore turn to stock prices and analyze the stock return responses to observed and latent surprises, where the latent surprises are extracted from bond yields only, as before. That is, the latent surprise is exactly what goes into our analysis before and does not mechanically load on stock prices at all.

Analyzing macroeconomic news' effects on stock prices involves a twist as observed surprises do not consistently affect equity returns. ${ }^{20}$ This is because perceived information from data releases about expected dividends and discount rates varies over time, which makes finding effects of news on stock prices nontrivial, since perceived news about dividends and discount rates affect stock prices in opposite directions. McQueen and Roley (1993); Boyd, Hu, and Jagannathan (2005), and Andersen et al. (2007) also make this observation and as a remedy suggest allowing for time-varying effect of news on stock prices, so that the net effect of news on stock prices may differ in expansions and recessions. We adopt that idea and extend it to accommodate separate effects of headline (observed) and latent (unobserved) news.

The measure of stock price reaction that we employ is the intraday return of the front S\&P500 futures contract from Tickdata (2020) and the specification that we estimate allows for the effect to vary by calendar year. We consider the specification in which only observed surprises affect returns:

$$
r_{t}=\sum_{j=1}^{J} \gamma_{S, j} c_{t, j} \beta^{\prime} s_{t}+\varepsilon_{t},
$$

where $r_{t}$ is the intraday stock futures return and $c_{t, j}$ is a sequence of dummy variables that is equal to 1 when observation $t$ is in calendar year $j, j=1, \ldots, J$. We also consider a version including the unobserved news:

$$
r_{t}=\sum_{j=1}^{J} \gamma_{S, j} c_{t, j}\left[\beta^{\prime} s_{t}+d_{t} f_{t}\right]+\varepsilon_{t} .
$$

\footnotetext{
${ }^{20}$ Note however that observed surprise changes of the target federal funds rate do significantly affect stock prices, as shown by Bernanke and Kuttner (2005).
} 

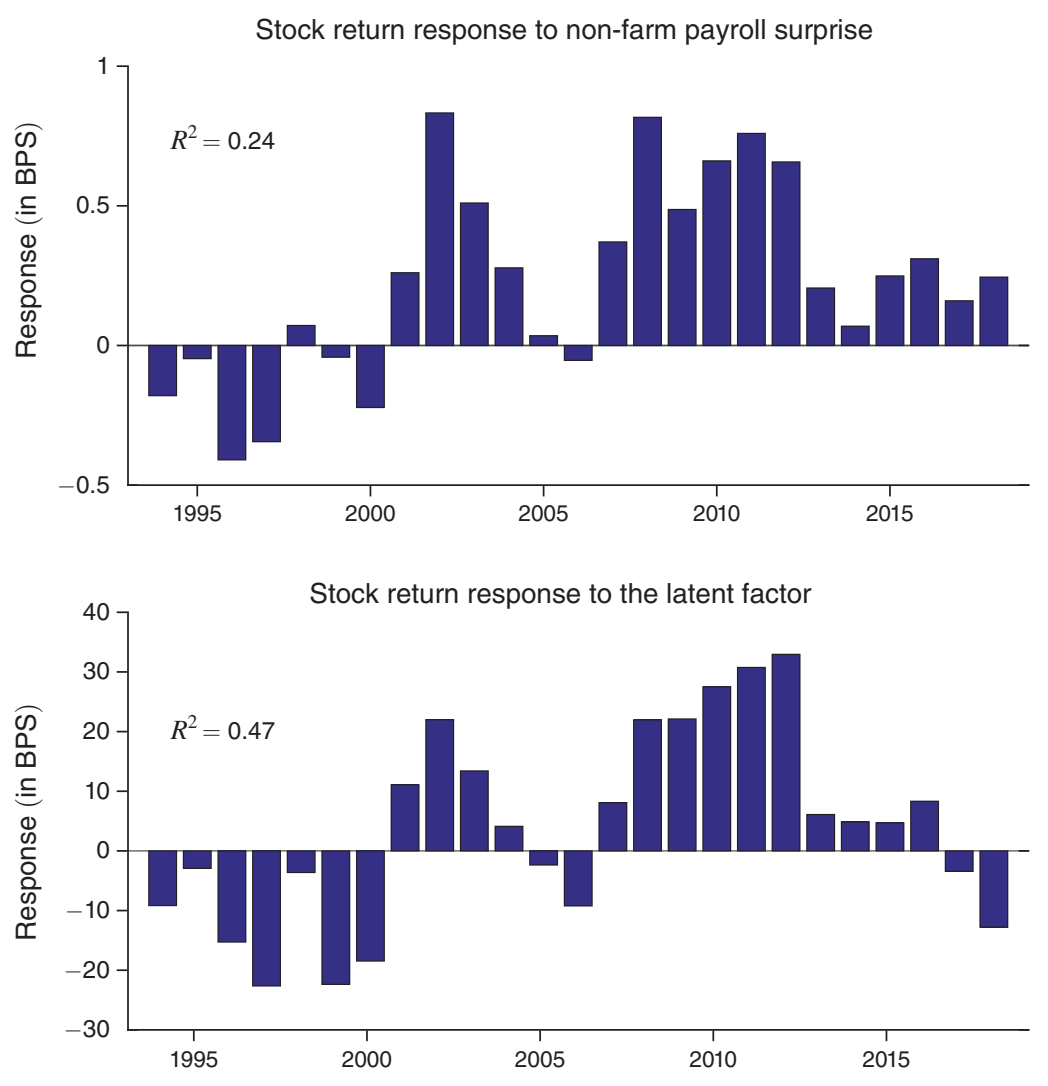

FIGURE 6

Notes: Time-varying response of stock returns to non-farm payroll surprise and the latent factor. These are obtained from estimating equation (11) (top panel) and equation (12) (bottom panel). The sample is 1994-2018.

Note that we are using the common latent variable, but we have already shown that release-specific latent variables differ only in scale. ${ }^{21}$

The upper panel of Figure 6 shows the effect of the nonfarm payrolls surprise on stock prices over time (other headline procyclical surprises have about the same pattern). This is obtained by multiplying the estimate of the calendar year dummy coefficients $\gamma_{S, j}$ by the estimate of $\beta$ corresponding to non-farm payrolls in equation (11). The lower panel of the same figure shows the effect of unobserved surprises on stock prices, based on multiplying the estimates of the calendar year dummy coefficients in equation (12). As one would expect if our understanding of multidimensional news releases is correct, the two panels are essentially the same: observed and unobserved surprises have had the same effects on stock prices. When the economy is growing quickly, as in the late 1990s, stronger-than-expected macroeconomic data lead to expectations of tighter monetary policy and lower stock prices through

\footnotetext{
${ }^{21}$ We use a common time dummy, $c_{t, j}$, for all the observed and unobserved news for parsimony, but using separate time dummies yields similar results.
} 

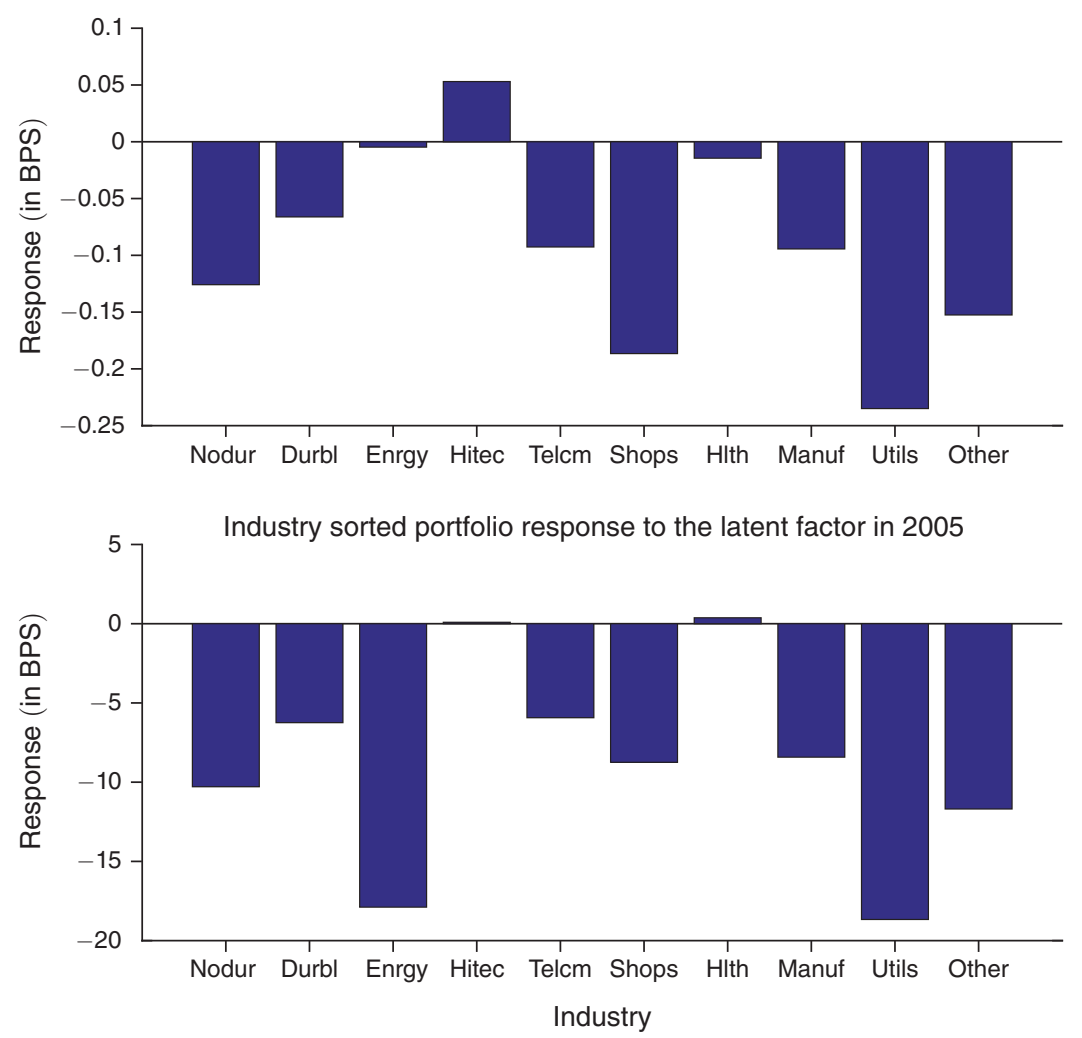

FigURE 7

Notes: Response of industry sorted portfolio returns to the non-farm payroll surprise and the latent factor in 2005. The sample is 1994-2018.

the discount rate channel. In recessions, or at the ZLB, stronger-than-expected macroeconomic data lead to higher stock prices through the growth channel and this is not offset by monetary policy expectations. This pattern of a state-dependent effect of news on the stock returns is similar to the findings of McQueen and Roley (1993); Boyd, Hu, and Jagannathan (2005); and Andersen et al. (2007), but those papers considered only observed headline surprises.

Including the latent news factor in the analysis once again doubles the $R^{2}$ but for stock prices the fraction of variance explained is not near unity. This poses an interesting question about stock pricing and stock-bond correlations that we do not try to answer here. Instead, we turn to industry sorted portfolios' responses to observed and latent surprises.

Figure 7 presents various industry stock portfolios' responses from French (2020) to surprises for one illustrative year, 2005. Results for other years are shown in online Appendix Section E. Figure 6 had shown that overall S\&P500 index response is the same for observed and unobserved surprises over time. Figure 7 now shows that effects of these two types of surprises on different industry stocks are also the same within a given year. Remembering that the unobserved news factor is 
recovered from bond prices only, with no stock price input, Figures 6 and 7 provide independent and striking verification that macroeconomic news releases are multidimensional, with only some dimensions observable to the econometrician, and that surprises have similar effects on asset prices regardless of whether the econometrician observes them. News explains a lot more of stock price movements in event windows compared to what was thought. Our results are not limited to bond prices.

\section{B. Pre-Crisis Sample and Ever-Present Level Factor}

We take on the next two issues simultaneously. We limit the sample to the pre-crisis period and introduce a new latent factor that is ever-present. This is in the spirit of Altavilla, Giannone, and Modugno (2017), who argue for the presence of a yield curve factor that is present on announcement and non-announcement days alike and is not driven by news. The ever-present factor is identified using the yield change covariances on non-announcement days. The extended model that we estimate is

$$
y_{t}=\beta^{\prime} s_{t}+\sum_{i=1}^{I} d_{i t} \gamma_{i} f_{i t}+\gamma_{0} f_{0 t}+\varepsilon_{t}
$$

and applies on all days, as before. The new factor $f_{0 t}$ affects yields on all days, whether they have announcements or not and captures the "background" common movement in asset prices that would be present even without any announcement. This latent factor turns out to be a level factor and we refer to it as the "ever-present" level factor. It does not have the hump shape that we saw for the effects of news announcements on yields. ${ }^{22}$

Maximum-likelihood estimates are reported in Table 9. This shows that our results hold even more strongly in the pre-crisis period. Thus our results are not driven by the somewhat unusual behavior of the yield curve in the ZLB period. More importantly, the results also show that introducing an ever-present level factor does not detract from the importance of non-headline statement factors. That is, the effect introduced by the non-headline news factor is distinct from the background factor that is always present. This exercise also reports marginal $R^{2}$ measures for headline surprises, non-headline latent factors, and the ever-present level factor. ${ }^{23}$ We observe that $R^{2}$ values are below 40 percent when only the headline surprises are included, increase substantially to about 90 percent when the latent non-announcement factors are included, and increase further when the common background factor is also included. When the ever-present level factor is not separately included in the analysis, it is partly absorbed by the latent factor, which mildly inflates the $R^{2}$ contribution of the latent factor. However, the announcement latent factors still play a very large role even after the ever-present level factor is included.

\footnotetext{
${ }^{22}$ Mechanically, there is nothing in our method that rules out the two latent variables having the same shape. If both the ever-present and the unobserved surprise latent variables were hump shaped or level factors, we would still identify them by the changes in variances in event and nonevent windows. If the unobserved surprise latent variable was only proxying for ever-present level, we would have seen that in this application.

${ }^{23}$ These regressors have negligible covariance with each other, so that changes in $R^{2}$ can be interpreted as marginal $R^{2}$ measures.
} 
Table 9-Estimates of Equation (13)

\begin{tabular}{|c|c|c|c|c|c|c|}
\hline & ED1 & ED4 & 2-year & 5-year & 10-year & 30-year \\
\hline Non-farm & $\begin{array}{c}3.82 \\
(0.21)\end{array}$ & $\begin{array}{c}7.03 \\
(0.36)\end{array}$ & $\begin{array}{c}5.49 \\
(0.29)\end{array}$ & $\begin{array}{c}6.06 \\
(0.31)\end{array}$ & $\begin{array}{c}4.46 \\
(0.24)\end{array}$ & $\begin{array}{c}2.59 \\
(0.15)\end{array}$ \\
\hline Initial claims & $\begin{array}{l}-0.47 \\
(0.03)\end{array}$ & $\begin{array}{l}-0.88 \\
(0.05)\end{array}$ & $\begin{array}{l}-0.69 \\
(0.04)\end{array}$ & $\begin{array}{l}-0.73 \\
(0.04)\end{array}$ & $\begin{array}{l}-0.56 \\
(0.03)\end{array}$ & $\begin{array}{l}-0.32 \\
(0.02)\end{array}$ \\
\hline Durable & $\begin{array}{c}0.69 \\
(0.08)\end{array}$ & $\begin{array}{c}1.35 \\
(0.15)\end{array}$ & $\begin{array}{c}1.01 \\
(0.12)\end{array}$ & $\begin{array}{c}1.19 \\
(0.12)\end{array}$ & $\begin{array}{c}0.81 \\
(0.10)\end{array}$ & $\begin{array}{c}0.51 \\
(0.06)\end{array}$ \\
\hline Emp cost & $\begin{array}{c}0.82 \\
(0.15)\end{array}$ & $\begin{array}{c}1.80 \\
(0.33)\end{array}$ & $\begin{array}{c}1.36 \\
(0.26)\end{array}$ & $\begin{array}{c}1.71 \\
(0.30)\end{array}$ & $\begin{array}{c}1.34 \\
(0.23)\end{array}$ & $\begin{array}{c}0.92 \\
(0.17)\end{array}$ \\
\hline Retail & $\begin{array}{c}0.31 \\
(0.12)\end{array}$ & $\begin{array}{c}0.82 \\
(0.17)\end{array}$ & $\begin{array}{c}0.63 \\
(0.12)\end{array}$ & $\begin{array}{c}0.54 \\
(0.13)\end{array}$ & $\begin{array}{c}0.35 \\
(0.11)\end{array}$ & $\begin{array}{c}0.09 \\
(0.08)\end{array}$ \\
\hline Retail ex. auto & $\begin{array}{c}0.81 \\
(0.10)\end{array}$ & $\begin{array}{c}1.42 \\
(0.17)\end{array}$ & $\begin{array}{c}1.16 \\
(0.13)\end{array}$ & $\begin{array}{c}1.26 \\
(0.15)\end{array}$ & $\begin{array}{c}0.99 \\
(0.12)\end{array}$ & $\begin{array}{c}0.72 \\
(0.08)\end{array}$ \\
\hline GDP & $\begin{array}{c}0.89 \\
(0.10)\end{array}$ & $\begin{array}{c}2.28 \\
(0.20)\end{array}$ & $\begin{array}{c}1.61 \\
(0.14)\end{array}$ & $\begin{array}{c}2.03 \\
(0.17)\end{array}$ & $\begin{array}{c}1.48 \\
(0.14)\end{array}$ & $\begin{array}{c}0.82 \\
(0.10)\end{array}$ \\
\hline CPI & $\begin{array}{l}-0.03 \\
(0.08)\end{array}$ & $\begin{array}{l}-0.37 \\
(0.16)\end{array}$ & $\begin{array}{l}-0.18 \\
(0.12)\end{array}$ & $\begin{array}{l}-0.14 \\
(0.15)\end{array}$ & $\begin{array}{l}-0.03 \\
(0.12)\end{array}$ & $\begin{array}{c}0.09 \\
(0.09)\end{array}$ \\
\hline Core CPI & $\begin{array}{c}1.09 \\
(0.08)\end{array}$ & $\begin{array}{c}2.41 \\
(0.16)\end{array}$ & $\begin{array}{c}1.73 \\
(0.13)\end{array}$ & $\begin{array}{c}2.15 \\
(0.15)\end{array}$ & $\begin{array}{c}1.72 \\
(0.12)\end{array}$ & $\begin{array}{c}1.09 \\
(0.09)\end{array}$ \\
\hline PPI & $\begin{array}{c}0.17 \\
(0.07)\end{array}$ & $\begin{array}{c}0.32 \\
(0.13)\end{array}$ & $\begin{array}{c}0.27 \\
(0.11)\end{array}$ & $\begin{array}{c}0.36 \\
(0.11)\end{array}$ & $\begin{array}{c}0.37 \\
(0.09)\end{array}$ & $\begin{array}{c}0.25 \\
(0.07)\end{array}$ \\
\hline Core PPI & $\begin{array}{c}0.95 \\
(0.09)\end{array}$ & $\begin{array}{c}1.68 \\
(0.15)\end{array}$ & $\begin{array}{c}1.13 \\
(0.11)\end{array}$ & $\begin{array}{c}1.38 \\
(0.12)\end{array}$ & $\begin{array}{c}1.19 \\
(0.10)\end{array}$ & $\begin{array}{c}0.90 \\
(0.07)\end{array}$ \\
\hline Hourly earnings & $\begin{array}{c}1.26 \\
(0.18)\end{array}$ & $\begin{array}{c}2.26 \\
(0.24)\end{array}$ & $\begin{array}{c}1.77 \\
(0.19)\end{array}$ & $\begin{array}{c}2.19 \\
(0.24)\end{array}$ & $\begin{array}{c}1.79 \\
(0.18)\end{array}$ & $\begin{array}{c}1.17 \\
(0.12)\end{array}$ \\
\hline Unemp & $\begin{array}{l}-1.81 \\
(0.16)\end{array}$ & $\begin{array}{l}-2.56 \\
(0.28)\end{array}$ & $\begin{array}{l}-2.06 \\
(0.21)\end{array}$ & $\begin{array}{l}-2.04 \\
(0.23)\end{array}$ & $\begin{array}{l}-1.35 \\
(0.18)\end{array}$ & $\begin{array}{l}-0.74 \\
(0.12)\end{array}$ \\
\hline FOMC & $\begin{array}{c}0.57 \\
(0.04)\end{array}$ & $\begin{array}{c}0.42 \\
(0.04)\end{array}$ & $\begin{array}{c}0.27 \\
(0.04)\end{array}$ & $\begin{array}{c}0.14 \\
(0.04)\end{array}$ & $\begin{array}{c}0.03 \\
(0.02)\end{array}$ & $\begin{array}{l}-0.02 \\
(0.01)\end{array}$ \\
\hline$f_{C P I, t}$ & $\begin{array}{c}1.25 \\
(0.09)\end{array}$ & $\begin{array}{c}2.80 \\
(0.13)\end{array}$ & $\begin{array}{c}2.24 \\
(0.11)\end{array}$ & $\begin{array}{c}2.43 \\
(0.13)\end{array}$ & $\begin{array}{c}1.73 \\
(0.11)\end{array}$ & $\begin{array}{c}1.16 \\
(0.09)\end{array}$ \\
\hline$f_{\text {Durable }, t}$ & $\begin{array}{c}0.93 \\
(0.07)\end{array}$ & $\begin{array}{c}2.01 \\
(0.14)\end{array}$ & $\begin{array}{c}1.56 \\
(0.09)\end{array}$ & $\begin{array}{c}1.60 \\
(0.10)\end{array}$ & $\begin{array}{c}1.20 \\
(0.09)\end{array}$ & $\begin{array}{c}0.70 \\
(0.06)\end{array}$ \\
\hline$f_{\text {EmpCost } t}$ & $\begin{array}{c}1.26 \\
(0.17)\end{array}$ & $\begin{array}{c}3.34 \\
(0.35)\end{array}$ & $\begin{array}{c}2.64 \\
(0.28)\end{array}$ & $\begin{array}{c}3.20 \\
(0.44)\end{array}$ & $\begin{array}{c}2.42 \\
(0.38)\end{array}$ & $\begin{array}{c}1.81 \\
(0.21)\end{array}$ \\
\hline$f_{G D P, t}$ & $\begin{array}{c}2.03 \\
(0.38)\end{array}$ & $\begin{array}{c}3.40 \\
(0.35)\end{array}$ & $\begin{array}{c}2.38 \\
(0.32)\end{array}$ & $\begin{array}{c}2.75 \\
(0.41)\end{array}$ & $\begin{array}{c}2.12 \\
(0.33)\end{array}$ & $\begin{array}{c}1.15 \\
(0.19)\end{array}$ \\
\hline$f_{\text {Claims }, t}$ & $\begin{array}{c}0.69 \\
(0.06)\end{array}$ & $\begin{array}{c}1.49 \\
(0.10)\end{array}$ & $\begin{array}{c}0.94 \\
(0.05)\end{array}$ & $\begin{array}{c}0.90 \\
(0.06)\end{array}$ & $\begin{array}{c}0.53 \\
(0.05)\end{array}$ & $\begin{array}{c}0.27 \\
(0.04)\end{array}$ \\
\hline$f_{\text {NonFarm }, t}$ & $\begin{array}{c}3.52 \\
(0.16)\end{array}$ & $\begin{array}{c}6.26 \\
(0.27)\end{array}$ & $\begin{array}{c}4.96 \\
(0.18)\end{array}$ & $\begin{array}{c}5.40 \\
(0.24)\end{array}$ & $\begin{array}{c}3.83 \\
(0.21)\end{array}$ & $\begin{array}{c}2.34 \\
(0.15)\end{array}$ \\
\hline$f_{P P I, t}$ & $\begin{array}{c}1.64 \\
(0.12)\end{array}$ & $\begin{array}{c}2.97 \\
(0.18)\end{array}$ & $\begin{array}{c}2.35 \\
(0.10)\end{array}$ & $\begin{array}{c}2.60 \\
(0.14)\end{array}$ & $\begin{array}{c}2.02 \\
(0.11)\end{array}$ & $\begin{array}{c}1.42 \\
(0.08)\end{array}$ \\
\hline$f_{\text {Retail }, t}$ & $\begin{array}{c}1.91 \\
(0.14)\end{array}$ & $\begin{array}{c}3.37 \\
(0.23)\end{array}$ & $\begin{array}{c}2.30 \\
(0.13)\end{array}$ & $\begin{array}{c}2.33 \\
(0.16)\end{array}$ & $\begin{array}{c}1.64 \\
(0.12)\end{array}$ & $\begin{array}{c}0.88 \\
(0.08)\end{array}$ \\
\hline$f_{F O M C, t}$ & $\begin{array}{c}2.57 \\
(0.18)\end{array}$ & $\begin{array}{c}5.96 \\
(0.37)\end{array}$ & $\begin{array}{c}4.26 \\
(0.27)\end{array}$ & $\begin{array}{c}4.26 \\
(0.37)\end{array}$ & $\begin{array}{c}2.71 \\
(0.27)\end{array}$ & $\begin{array}{c}1.30 \\
(0.18)\end{array}$ \\
\hline$f_{0, t}$ & $\begin{array}{c}0.43 \\
(0.03)\end{array}$ & $\begin{array}{c}1.41 \\
(0.05)\end{array}$ & $\begin{array}{c}1.07 \\
(0.04)\end{array}$ & $\begin{array}{c}1.58 \\
(0.04)\end{array}$ & $\begin{array}{c}1.41 \\
(0.03)\end{array}$ & $\begin{array}{c}0.96 \\
(0.02)\end{array}$ \\
\hline$R^{2}$ no factor & 0.48 & 0.40 & 0.40 & 0.37 & 0.35 & 0.31 \\
\hline$R^{2}$ release factors & 0.87 & 0.90 & 0.90 & 0.83 & 0.75 & 0.66 \\
\hline$R^{2}$ all factors & 0.87 & 0.96 & 0.96 & 0.99 & 1.00 & 0.97 \\
\hline
\end{tabular}

Notes: Standard errors are in parentheses. See Table 3 for data description. The sample is 1992-2007. 


\section{Short-End Factor}

The methodology that we propose efficiently extracts the latent factor and the coefficients relating the headline surprises and the latent factor to yields at various maturities in one step. While the efficiency is desirable, information from long-term yields is used to estimate the factor, which in turn helps fit the changes in these yields. One worry therefore is whether we are mechanically explaining long-term yields with themselves.

To be sure that we are not, we sacrifice efficiency for a moment and use only information from the short-end of the yield curve, covering maturities up to one year. We then use this latent factor to help explain the changes in longer-term yields in the event window. This exercise can only be done with the pre-crisis sample as during the ZLB episode yields up to one year were stuck at their lower bounds and were not responsive to incoming data, as was persuasively shown by Swanson and Williams (2014).

Coefficient estimates and $R^{2}$ values from the two-step procedure are shown in Table 10. It is clear that the results are about the same, showing that the latent factor we extract from the short-end of the yield curve in the first step can explain the changes in the long-end as well.

\section{The Monetary Policy Path Surprise}

This exercise segues nicely into our next robustness check. Extracting latent factors from the short-end of the yield curve and rotating these to admit policy action and policy path surprise definitions was done by Gürkaynak, Sack, and Swanson (2005) - henceforth, GSS - for FOMC announcement windows and we use their data. Their policy action surprise mechanically coincides with our observed headline news. We now check whether their principal components and factor rotation-based two step procedure and our Kalman filtering-based method produce similar path (latent non-headline) factors. The GSS path factor has been extensively used in academic and policy work during the past decade to study the effects of forward guidance (Blinder et al. 2008, Campbell et al. 2012, Gertler and Karadi 2015). Verifying that the series we produce for FOMC non-headline news is close to that series would instill confidence that our macroeconomic data release latent factor, for which there is no comparison series, is also capturing non-headline news that are in the release.

Before turning to the results, it is worth briefly discussing why our method is not an application of GSS to macroeconomic data releases. GSS extract principal components from short-maturity yields, show that two factors are statistically present, and rotate those to make them interpretable. The presence of two separate factors in yields (and of course the availability of multiple asset returns) is crucial in that method. FOMC action (target) and statement (path) surprises affect the yield curve differently, which forms the basis of the GSS identification.

Here we have shown that observed and unobserved macroeconomic data surprises have the same effect on yields (and for that matter, on stocks). Hence, a GSS style, principal components-based approach would find only one factor for macroeconomic data releases but that factor would be imperfectly correlated with observable surprises. That would bring us back to square one, where we did not understand why 
TABLE 10

\begin{tabular}{|c|c|c|c|c|c|c|}
\hline & ED1 & ED4 & 2-year & 5-year & 10-year & 30-year \\
\hline Non-farm & $\begin{array}{c}3.82 \\
(0.17)\end{array}$ & $\begin{array}{c}7.04 \\
(0.24)\end{array}$ & $\begin{array}{c}5.49 \\
(0.19)\end{array}$ & $\begin{array}{c}6.06 \\
(0.23)\end{array}$ & $\begin{array}{c}4.46 \\
(0.23)\end{array}$ & $\begin{array}{c}2.59 \\
(0.17)\end{array}$ \\
\hline Initial claims & $\begin{array}{l}-0.45 \\
(0.02)\end{array}$ & $\begin{array}{l}-0.85 \\
(0.03)\end{array}$ & $\begin{array}{l}-0.65 \\
(0.05)\end{array}$ & $\begin{array}{l}-0.68 \\
(0.05)\end{array}$ & $\begin{array}{l}-0.52 \\
(0.04)\end{array}$ & $\begin{array}{l}-0.30 \\
(0.03)\end{array}$ \\
\hline Durable & $\begin{array}{c}0.64 \\
(0.04)\end{array}$ & $\begin{array}{c}1.27 \\
(0.06)\end{array}$ & $\begin{array}{c}0.95 \\
(0.10)\end{array}$ & $\begin{array}{c}1.12 \\
(0.09)\end{array}$ & $\begin{array}{c}0.77 \\
(0.08)\end{array}$ & $\begin{array}{c}0.48 \\
(0.06)\end{array}$ \\
\hline Emp cost & $\begin{array}{c}0.85 \\
(0.09)\end{array}$ & $\begin{array}{c}1.92 \\
(0.12)\end{array}$ & $\begin{array}{c}1.32 \\
(0.23)\end{array}$ & $\begin{array}{c}1.79 \\
(0.27)\end{array}$ & $\begin{array}{c}1.40 \\
(0.21)\end{array}$ & $\begin{array}{c}0.95 \\
(0.17)\end{array}$ \\
\hline Retail & $\begin{array}{c}0.36 \\
(0.06)\end{array}$ & $\begin{array}{c}1.01 \\
(0.08)\end{array}$ & $\begin{array}{c}0.74 \\
(0.12)\end{array}$ & $\begin{array}{c}0.66 \\
(0.13)\end{array}$ & $\begin{array}{c}0.44 \\
(0.09)\end{array}$ & $\begin{array}{c}0.16 \\
(0.07)\end{array}$ \\
\hline Retail ex. auto & $\begin{array}{c}0.82 \\
(0.06)\end{array}$ & $\begin{array}{c}1.45 \\
(0.10)\end{array}$ & $\begin{array}{c}1.19 \\
(0.15)\end{array}$ & $\begin{array}{c}1.27 \\
(0.16)\end{array}$ & $\begin{array}{c}1.00 \\
(0.12)\end{array}$ & $\begin{array}{c}0.72 \\
(0.10)\end{array}$ \\
\hline GDP & $\begin{array}{c}0.86 \\
(0.10)\end{array}$ & $\begin{array}{c}2.22 \\
(0.13)\end{array}$ & $\begin{array}{c}1.58 \\
(0.20)\end{array}$ & $\begin{array}{c}2.02 \\
(0.25)\end{array}$ & $\begin{array}{l}1.48 \\
(0.22)\end{array}$ & $\begin{array}{c}0.84 \\
(0.18)\end{array}$ \\
\hline CPI & $\begin{array}{l}-0.04 \\
(0.06)\end{array}$ & $\begin{array}{l}-0.31 \\
(0.09)\end{array}$ & $\begin{array}{l}-0.24 \\
(0.11)\end{array}$ & $\begin{array}{l}-0.14 \\
(0.14)\end{array}$ & $\begin{array}{l}-0.03 \\
(0.12)\end{array}$ & $\begin{array}{c}0.09 \\
(0.11)\end{array}$ \\
\hline Core CPI & $\begin{array}{c}1.13 \\
(0.05)\end{array}$ & $\begin{array}{c}2.59 \\
(0.09)\end{array}$ & $\begin{array}{c}1.76 \\
(0.13)\end{array}$ & $\begin{array}{c}2.19 \\
(0.14)\end{array}$ & $\begin{array}{l}1.75 \\
(0.13)\end{array}$ & $\begin{array}{c}1.11 \\
(0.11)\end{array}$ \\
\hline PPI & $\begin{array}{c}0.13 \\
(0.04)\end{array}$ & $\begin{array}{c}0.25 \\
(0.06)\end{array}$ & $\begin{array}{c}0.20 \\
(0.09)\end{array}$ & $\begin{array}{c}0.30 \\
(0.10)\end{array}$ & $\begin{array}{c}0.33 \\
(0.08)\end{array}$ & $\begin{array}{c}0.23 \\
(0.07)\end{array}$ \\
\hline Core PPI & $\begin{array}{c}0.87 \\
(0.05)\end{array}$ & $\begin{array}{c}1.79 \\
(0.09)\end{array}$ & $\begin{array}{c}1.04 \\
(0.11)\end{array}$ & $\begin{array}{c}1.29 \\
(0.13)\end{array}$ & $\begin{array}{c}1.13 \\
(0.11)\end{array}$ & $\begin{array}{c}0.87 \\
(0.09)\end{array}$ \\
\hline Hourly earnings & $\begin{array}{c}1.25 \\
(0.14)\end{array}$ & $\begin{array}{c}2.27 \\
(0.20)\end{array}$ & $\begin{array}{c}1.79 \\
(0.19)\end{array}$ & $\begin{array}{c}2.19 \\
(0.20)\end{array}$ & $\begin{array}{c}1.79 \\
(0.19)\end{array}$ & $\begin{array}{c}1.17 \\
(0.15)\end{array}$ \\
\hline Unemp & $\begin{array}{l}-1.81 \\
(0.10)\end{array}$ & $\begin{array}{l}-2.57 \\
(0.14)\end{array}$ & $\begin{array}{l}-2.04 \\
(0.17)\end{array}$ & $\begin{array}{l}-2.04 \\
(0.21)\end{array}$ & $\begin{array}{l}-1.35 \\
(0.18)\end{array}$ & $\begin{array}{l}-0.74 \\
(0.13)\end{array}$ \\
\hline FOMC & $\begin{array}{c}0.57 \\
(0.03)\end{array}$ & $\begin{array}{c}0.38 \\
(0.05)\end{array}$ & $\begin{array}{c}0.27 \\
(0.03)\end{array}$ & $\begin{array}{c}0.14 \\
(0.04)\end{array}$ & $\begin{array}{c}0.03 \\
(0.04)\end{array}$ & $\begin{array}{l}-0.02 \\
(0.03)\end{array}$ \\
\hline Factor & $\begin{array}{c}2.18 \\
(0.05)\end{array}$ & $\begin{array}{c}4.23 \\
(0.09)\end{array}$ & $\begin{array}{c}2.85 \\
(0.08)\end{array}$ & $\begin{array}{c}3.23 \\
(0.08)\end{array}$ & $\begin{array}{c}2.41 \\
(0.07)\end{array}$ & $\begin{array}{c}1.49 \\
(0.05)\end{array}$ \\
\hline$R^{2}$ no factor & 0.48 & 0.40 & 0.40 & 0.37 & 0.35 & 0.31 \\
\hline$R^{2}$ with factor & 0.93 & 0.95 & 0.86 & 0.86 & 0.82 & 0.74 \\
\hline
\end{tabular}

Notes: Same as for Table 3, except that in estimating the latent factor, only ED1 and ED4 are used. Other yield changes are regressed on the estimated latent factor. The sample is 1992-2007.

yield changes in event windows are not explained by observable macroeconomic surprises. Thus, methods based only on principal components would not work here, observable and latent surprises which may (and do) have the same effects on yields must be brought in at the outset. The Kalman filter we proposed does this efficiently and would also work if only a single asset is available. ${ }^{24}$

Turning to the results now, Figure 8 shows the paths of the Gürkaynak, Sack, and Swanson (2005) path factor and our latent FOMC factor based on the pre-crisis sample. The close correspondence between the two series is impressive: the two series have a correlation of 87 percent. Hence, the methodology that we propose in this paper does in one step what was done in two steps by GSS, but finds the same

\footnotetext{
${ }^{24}$ Identification would exploit event and nonevent window data for an asset that is affected by both factors, as explained before.
} 


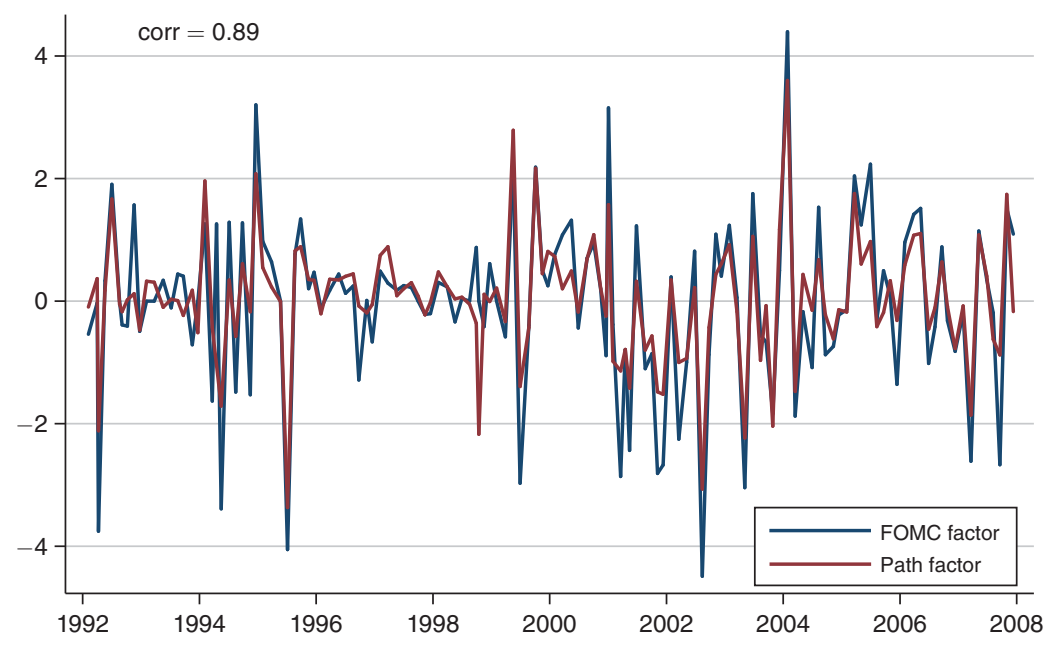

Figure 8

Notes: Comparison of Gürkaynak, Sack, and Swanson (2005) path factor and the estimated latent factor. The path factor is standardized to have unit variance. The latent factor estimated from monetary policy surprises and the asset price responses around monetary policy announcements. The sample is 1992-2007.

latent path factor. This makes it easier to be assured that the latent factors extracted for other macroeconomic data releases are also measures of non-headline news as perceived by market participants.

\section{E. Generalized Variance-Covariance Matrix}

As another robustness check, instead of having a diagonal variance-covariance matrix for $\varepsilon_{t}$ in equations $(7)$ and $(8)$, we allow for an unrestricted variance-covariance matrix for the background noise. Thus the variance-covariance matrix now incorporates any ever-present factor (like the one considered in equation (13)), which is not separately identified any more.

This model can also be estimated by maximum likelihood, and the results are reported in Table 11, for the case with a single latent factor and Table 12, with release-specific factors. Having unrestricted noise makes no difference for our results. As is the case in the benchmark model where $\varepsilon_{t}$ has a diagonal variance-covariance matrix, the OLS coefficients are essentially unchanged from those reported in Table 1. And it remains the case that the measured surprise plus one latent factor are sufficient to explain the vast majority of yield curve movements around announcements.

\section{F. Lower Frequency Effects}

Up to this point we focused on asset price responses in tight intraday windows. As a final robustness check, it is useful to study yield changes and how they relate to observable and latent surprises at other, lower, frequencies. We do this in two 
TABLE 11

\begin{tabular}{|c|c|c|c|c|c|c|}
\hline & ED1 & ED4 & 2-year & 5-year & 10-year & 30-year \\
\hline Non-farm & $\begin{array}{c}2.87 \\
(0.16)\end{array}$ & $\begin{array}{c}5.67 \\
(0.24)\end{array}$ & $\begin{array}{c}4.46 \\
(0.20)\end{array}$ & $\begin{array}{c}5.26 \\
(0.21)\end{array}$ & $\begin{array}{c}3.97 \\
(0.16)\end{array}$ & $\begin{array}{c}2.41 \\
(0.11)\end{array}$ \\
\hline Initial claims & $\begin{array}{l}-0.30 \\
(0.02)\end{array}$ & $\begin{array}{l}-0.73 \\
(0.04)\end{array}$ & $\begin{array}{l}-0.56 \\
(0.03)\end{array}$ & $\begin{array}{l}-0.66 \\
(0.03)\end{array}$ & $\begin{array}{l}-0.53 \\
(0.03)\end{array}$ & $\begin{array}{l}-0.32 \\
(0.02)\end{array}$ \\
\hline Durable & $\begin{array}{c}0.38 \\
(0.06)\end{array}$ & $\begin{array}{c}0.87 \\
(0.11)\end{array}$ & $\begin{array}{c}0.66 \\
(0.08)\end{array}$ & $\begin{array}{c}0.83 \\
(0.09)\end{array}$ & $\begin{array}{c}0.58 \\
(0.08)\end{array}$ & $\begin{array}{c}0.37 \\
(0.05)\end{array}$ \\
\hline Emp cost & $\begin{array}{c}0.68 \\
(0.10)\end{array}$ & $\begin{array}{c}1.48 \\
(0.22)\end{array}$ & $\begin{array}{c}1.13 \\
(0.17)\end{array}$ & $\begin{array}{c}1.48 \\
(0.21)\end{array}$ & $\begin{array}{c}1.15 \\
(0.16)\end{array}$ & $\begin{array}{c}0.74 \\
(0.11)\end{array}$ \\
\hline Retail & $\begin{array}{c}0.31 \\
(0.09)\end{array}$ & $\begin{array}{c}0.77 \\
(0.12)\end{array}$ & $\begin{array}{c}0.59 \\
(0.09)\end{array}$ & $\begin{array}{c}0.54 \\
(0.11)\end{array}$ & $\begin{array}{c}0.38 \\
(0.10)\end{array}$ & $\begin{array}{c}0.14 \\
(0.07)\end{array}$ \\
\hline Retail ex. auto & $\begin{array}{c}0.40 \\
(0.07)\end{array}$ & $\begin{array}{c}0.95 \\
(0.13)\end{array}$ & $\begin{array}{c}0.84 \\
(0.10)\end{array}$ & $\begin{array}{c}1.16 \\
(0.11)\end{array}$ & $\begin{array}{c}0.92 \\
(0.09)\end{array}$ & $\begin{array}{c}0.70 \\
(0.07)\end{array}$ \\
\hline $\mathrm{CPI}$ & $\begin{array}{c}0.01 \\
(0.05)\end{array}$ & $\begin{array}{l}-0.05 \\
(0.11)\end{array}$ & $\begin{array}{l}-0.01 \\
(0.08)\end{array}$ & $\begin{array}{c}0.10 \\
(0.10)\end{array}$ & $\begin{array}{c}0.15 \\
(0.08)\end{array}$ & $\begin{array}{l}0.19 \\
0.06\end{array}$ \\
\hline GDP & $\begin{array}{c}0.66 \\
(0.07)\end{array}$ & $\begin{array}{c}1.61 \\
(0.17)\end{array}$ & $\begin{array}{c}1.18 \\
(0.12)\end{array}$ & $\begin{array}{c}1.59 \\
(0.15)\end{array}$ & $\begin{array}{c}1.21 \\
(0.12)\end{array}$ & $\begin{array}{c}0.70 \\
(0.08)\end{array}$ \\
\hline Core CPI & $\begin{array}{c}0.72 \\
(0.06)\end{array}$ & $\begin{array}{c}1.69 \\
(0.11)\end{array}$ & $\begin{array}{c}1.25 \\
(0.09)\end{array}$ & $\begin{array}{c}1.56 \\
(0.10)\end{array}$ & $\begin{array}{c}1.27 \\
(0.08)\end{array}$ & $\begin{array}{c}0.81 \\
(0.06)\end{array}$ \\
\hline PPI & $\begin{array}{c}0.11 \\
(0.05)\end{array}$ & $\begin{array}{c}0.25 \\
(0.09)\end{array}$ & $\begin{array}{c}0.17 \\
(0.07)\end{array}$ & $\begin{array}{c}0.18 \\
(0.08)\end{array}$ & $\begin{array}{c}0.23 \\
(0.06)\end{array}$ & $\begin{array}{c}0.16 \\
(0.04)\end{array}$ \\
\hline Core PPI & $\begin{array}{c}0.60 \\
(0.06)\end{array}$ & $\begin{array}{c}1.09 \\
(0.10)\end{array}$ & $\begin{array}{c}0.77 \\
(0.08)\end{array}$ & $\begin{array}{c}1.03 \\
(0.08)\end{array}$ & $\begin{array}{c}0.89 \\
(0.07)\end{array}$ & $\begin{array}{c}0.68 \\
(0.05)\end{array}$ \\
\hline Hourly earnings & $\begin{array}{c}0.88 \\
(0.12)\end{array}$ & $\begin{array}{c}1.85 \\
(0.17)\end{array}$ & $\begin{array}{c}1.44 \\
(0.14)\end{array}$ & $\begin{array}{c}2.02 \\
(0.17)\end{array}$ & $\begin{array}{c}1.61 \\
(0.13)\end{array}$ & $\begin{array}{c}0.97 \\
(0.09)\end{array}$ \\
\hline Unemp & $\begin{array}{l}-1.23 \\
(0.11)\end{array}$ & $\begin{array}{l}-2.05 \\
(0.18)\end{array}$ & $\begin{array}{l}-1.64 \\
(0.14)\end{array}$ & $\begin{array}{l}-1.70 \\
(0.15)\end{array}$ & $\begin{array}{c}-1.18 \\
(0.12)\end{array}$ & $\begin{array}{l}-0.68 \\
(0.08)\end{array}$ \\
\hline FOMC & $\begin{array}{c}0.57 \\
(0.04)\end{array}$ & $\begin{array}{c}0.41 \\
(0.04)\end{array}$ & $\begin{array}{c}0.28 \\
(0.04)\end{array}$ & $\begin{array}{c}0.14 \\
(0.04)\end{array}$ & $\begin{array}{c}0.03 \\
(0.02)\end{array}$ & $\begin{array}{l}-0.02 \\
(0.01)\end{array}$ \\
\hline Factor & $\begin{array}{l}1.36 \\
0.06\end{array}$ & $\begin{array}{l}3.09 \\
0.06\end{array}$ & $\begin{array}{l}2.32 \\
0.04\end{array}$ & $\begin{array}{l}2.65 \\
0.06\end{array}$ & $\begin{array}{l}1.94 \\
0.05\end{array}$ & $\begin{array}{l}1.17 \\
0.04\end{array}$ \\
\hline$R^{2}$ no factor & 0.40 & 0.36 & 0.37 & 0.36 & 0.34 & 0.30 \\
\hline$R^{2}$ with factor & 0.77 & 0.97 & 0.96 & 0.93 & 0.85 & 0.72 \\
\hline
\end{tabular}

Note: Same as for Table 3, except with an unrestricted variance-covariance matrix for the background noise.

ways, first keeping the structure up to now unchanged but studying wider intraday, and daily window reactions; then studying yield responses at monthly and quarterly frequencies, which require augmenting our method using the aggregation idea proposed by Altavilla, Giannone, and Modugno (2017).

Wider Event Windows. - To verify window size robustness, we estimate equation (7) for a wide window ( 5 minutes before and 85 minutes after the announcement) and for the daily window. For both of these exercises, we allow an unrestricted variance covariance matrix for the background noise.

The results are given in Tables 13 and 14. Consistent with the earlier results, headline surprises explain less than 40 percent of the wide event window variation in yields and one latent factor substantially increases $R^{2}$ values above 90 percent for most maturities. 
TABLE 12

\begin{tabular}{|c|c|c|c|c|c|c|}
\hline & ED1 & ED4 & 2-year & 5 -year & 10-year & 30-year \\
\hline Non-farm & $\begin{array}{c}2.86 \\
(0.16)\end{array}$ & $\begin{array}{c}5.66 \\
(0.24)\end{array}$ & $\begin{array}{c}4.45 \\
(0.20)\end{array}$ & $\begin{array}{c}5.26 \\
(0.21)\end{array}$ & $\begin{array}{c}3.97 \\
(0.16)\end{array}$ & $\begin{array}{c}2.40 \\
(0.11)\end{array}$ \\
\hline Initial claims & $\begin{array}{l}-0.31 \\
(0.02)\end{array}$ & $\begin{array}{l}-0.74 \\
(0.03)\end{array}$ & $\begin{array}{l}-0.58 \\
(0.02)\end{array}$ & $\begin{array}{c}-0.6 \\
(0.03)\end{array}$ & $\begin{array}{c}-0.5 \\
(0.02)\end{array}$ & $\begin{array}{l}-0.33 \\
(0.02)\end{array}$ \\
\hline Durable & $\begin{array}{c}0.39 \\
(0.06)\end{array}$ & $\begin{array}{c}0.9 \\
(0.11)\end{array}$ & $\begin{array}{c}0.67 \\
(0.09)\end{array}$ & $\begin{array}{c}0.84 \\
(0.10)\end{array}$ & $\begin{array}{c}0.59 \\
(0.08)\end{array}$ & $\begin{array}{c}0.38 \\
(0.05)\end{array}$ \\
\hline Emp cost & $\begin{array}{c}0.72 \\
(0.11)\end{array}$ & $\begin{array}{c}1.55 \\
(0.22)\end{array}$ & $\begin{array}{c}1.18 \\
(0.18)\end{array}$ & $\begin{array}{c}1.54 \\
(0.22)\end{array}$ & $\begin{array}{c}1.20 \\
(0.17)\end{array}$ & $\begin{array}{c}0.77 \\
(0.11)\end{array}$ \\
\hline Retail & $\begin{array}{c}0.25 \\
(0.08)\end{array}$ & $\begin{array}{c}0.65 \\
(0.11)\end{array}$ & $\begin{array}{c}0.49 \\
(0.08)\end{array}$ & $\begin{array}{c}0.42 \\
(0.10)\end{array}$ & $\begin{array}{c}0.29 \\
(0.08)\end{array}$ & $\begin{array}{c}0.08 \\
(0.06)\end{array}$ \\
\hline Retail ex. auto & $\begin{array}{c}0.42 \\
(0.07)\end{array}$ & $\begin{array}{c}1.01 \\
(0.12)\end{array}$ & $\begin{array}{c}0.89 \\
(0.09)\end{array}$ & $\begin{array}{c}1.21 \\
(0.11)\end{array}$ & $\begin{array}{c}0.96 \\
(0.09)\end{array}$ & $\begin{array}{c}0.73 \\
(0.06)\end{array}$ \\
\hline GDP & $\begin{array}{c}0.69 \\
(0.07)\end{array}$ & $\begin{array}{c}1.70 \\
(0.15)\end{array}$ & $\begin{array}{c}1.26 \\
(0.10)\end{array}$ & $\begin{array}{c}1.68 \\
(0.13)\end{array}$ & $\begin{array}{c}1.28 \\
(0.11)\end{array}$ & $\begin{array}{c}0.75 \\
(0.07)\end{array}$ \\
\hline CPI & $\begin{array}{c}0.01 \\
(0.05)\end{array}$ & $\begin{array}{l}-0.05 \\
(0.11)\end{array}$ & $\begin{array}{l}-0.01 \\
(0.08)\end{array}$ & $\begin{array}{c}0.11 \\
(0.10)\end{array}$ & $\begin{array}{c}0.15 \\
(0.08)\end{array}$ & $\begin{array}{c}0.20 \\
(0.06)\end{array}$ \\
\hline Core CPI & $\begin{array}{c}0.68 \\
(0.05)\end{array}$ & $\begin{array}{c}1.61 \\
(0.11)\end{array}$ & $\begin{array}{c}1.19 \\
(0.08)\end{array}$ & $\begin{array}{c}1.50 \\
(0.10)\end{array}$ & $\begin{array}{c}1.23 \\
(0.08)\end{array}$ & $\begin{array}{c}0.78 \\
(0.06)\end{array}$ \\
\hline PPI & $\begin{array}{c}0.12 \\
(0.05)\end{array}$ & $\begin{array}{c}0.27 \\
(0.09)\end{array}$ & $\begin{array}{c}0.19 \\
(0.07)\end{array}$ & $\begin{array}{c}0.20 \\
(0.08)\end{array}$ & $\begin{array}{c}0.24 \\
(0.06)\end{array}$ & $\begin{array}{c}0.17 \\
(0.05)\end{array}$ \\
\hline Core PPI & $\begin{array}{c}0.63 \\
(0.07)\end{array}$ & $\begin{array}{c}1.14 \\
(0.10)\end{array}$ & $\begin{array}{c}0.81 \\
(0.08)\end{array}$ & $\begin{array}{c}1.07 \\
(0.09)\end{array}$ & $\begin{array}{c}0.92 \\
(0.07)\end{array}$ & $\begin{array}{c}0.70 \\
(0.05)\end{array}$ \\
\hline Hourly earnings & $\begin{array}{c}0.88 \\
(0.12)\end{array}$ & $\begin{array}{c}1.85 \\
(0.17)\end{array}$ & $\begin{array}{c}1.44 \\
(0.14)\end{array}$ & $\begin{array}{c}2.02 \\
(0.17)\end{array}$ & $\begin{array}{c}1.61 \\
(0.13)\end{array}$ & $\begin{array}{c}0.97 \\
(0.09)\end{array}$ \\
\hline Unemp & $\begin{array}{l}-1.23 \\
(0.11)\end{array}$ & $\begin{array}{l}-2.05 \\
(0.18)\end{array}$ & $\begin{array}{l}-1.64 \\
(0.14)\end{array}$ & $\begin{array}{l}-1.70 \\
(0.15)\end{array}$ & $\begin{array}{c}-1.18 \\
(0.12)\end{array}$ & $\begin{array}{l}-0.68 \\
(0.08)\end{array}$ \\
\hline FOMC & $\begin{array}{c}0.57 \\
(0.04)\end{array}$ & $\begin{array}{c}0.41 \\
(0.04)\end{array}$ & $\begin{array}{c}0.28 \\
(0.04)\end{array}$ & $\begin{array}{c}0.14 \\
(0.04)\end{array}$ & $\begin{array}{c}0.03 \\
(0.02)\end{array}$ & $\begin{array}{l}-0.02 \\
(0.01)\end{array}$ \\
\hline$f_{C P I, t}$ & $\begin{array}{c}1.07 \\
(0.07)\end{array}$ & $\begin{array}{c}2.52 \\
(0.10)\end{array}$ & $\begin{array}{c}2.01 \\
(0.08)\end{array}$ & $\begin{array}{c}2.39 \\
(0.09)\end{array}$ & $\begin{array}{c}1.81 \\
(0.07)\end{array}$ & $\begin{array}{c}1.24 \\
(0.06)\end{array}$ \\
\hline$f_{\text {Durable }, t}$ & $\begin{array}{c}0.64 \\
(0.13)\end{array}$ & $\begin{array}{c}1.82 \\
(0.11)\end{array}$ & $\begin{array}{c}1.35 \\
(0.07)\end{array}$ & $\begin{array}{c}1.50 \\
(0.08)\end{array}$ & $\begin{array}{c}1.18 \\
(0.07)\end{array}$ & $\begin{array}{c}0.74 \\
(0.05)\end{array}$ \\
\hline$f_{\text {EmpCost }, t}$ & $\begin{array}{c}0.73 \\
(0.16)\end{array}$ & $\begin{array}{c}2.38 \\
(0.29)\end{array}$ & $\begin{array}{c}2.03 \\
(0.19)\end{array}$ & $\begin{array}{c}2.51 \\
(0.26)\end{array}$ & $\begin{array}{c}1.88 \\
(0.22)\end{array}$ & $\begin{array}{c}1.30 \\
(0.15)\end{array}$ \\
\hline$f_{G D P, t}$ & $\begin{array}{c}1.41 \\
(0.34)\end{array}$ & $\begin{array}{c}2.99 \\
(0.20)\end{array}$ & $\begin{array}{c}2.11 \\
(0.18)\end{array}$ & $\begin{array}{c}2.57 \\
(0.20)\end{array}$ & $\begin{array}{c}2.05 \\
(0.16)\end{array}$ & $\begin{array}{c}1.19 \\
(0.11)\end{array}$ \\
\hline$f_{\text {Claims }, t}$ & $\begin{array}{c}0.49 \\
(0.05)\end{array}$ & $\begin{array}{c}1.22 \\
(0.07)\end{array}$ & $\begin{array}{c}0.81 \\
(0.04)\end{array}$ & $\begin{array}{c}0.95 \\
(0.05)\end{array}$ & $\begin{array}{c}0.69 \\
(0.04)\end{array}$ & $\begin{array}{c}0.40 \\
(0.03)\end{array}$ \\
\hline$f_{\text {NonFarm }, t}$ & $\begin{array}{c}2.76 \\
(0.18)\end{array}$ & $\begin{array}{c}5.71 \\
(0.18)\end{array}$ & $\begin{array}{c}4.48 \\
(0.13)\end{array}$ & $\begin{array}{c}5.13 \\
(0.20)\end{array}$ & $\begin{array}{c}3.70 \\
(0.20)\end{array}$ & $\begin{array}{c}2.16 \\
(0.16)\end{array}$ \\
\hline$f_{P P I, t}$ & $\begin{array}{c}1.32 \\
(0.13)\end{array}$ & $\begin{array}{c}2.32 \\
(0.12)\end{array}$ & $\begin{array}{c}1.86 \\
(0.08)\end{array}$ & $\begin{array}{c}2.14 \\
(0.10)\end{array}$ & $\begin{array}{c}1.74 \\
(0.09)\end{array}$ & $\begin{array}{c}1.20 \\
(0.06)\end{array}$ \\
\hline$f_{\text {Retail }, t}$ & $\begin{array}{c}1.37 \\
(0.16)\end{array}$ & $\begin{array}{c}2.99 \\
(0.18)\end{array}$ & $\begin{array}{c}2.09 \\
(0.10)\end{array}$ & $\begin{array}{c}2.21 \\
(0.12)\end{array}$ & $\begin{array}{c}1.64 \\
(0.10)\end{array}$ & $\begin{array}{c}0.93 \\
(0.08)\end{array}$ \\
\hline$f_{F O M C, t}$ & $\begin{array}{c}2.17 \\
(0.30)\end{array}$ & $\begin{array}{c}6.34 \\
(0.34)\end{array}$ & $\begin{array}{c}4.52 \\
(0.24)\end{array}$ & $\begin{array}{c}4.85 \\
(0.35)\end{array}$ & $\begin{array}{c}3.27 \\
(0.25)\end{array}$ & $\begin{array}{c}1.73 \\
(0.18)\end{array}$ \\
\hline$R^{2}$ no factor & 0.40 & 0.36 & 0.37 & 0.36 & 0.34 & 0.30 \\
\hline$R^{2}$ release factors & 0.77 & 0.96 & 0.96 & 0.92 & 0.84 & 0.72 \\
\hline
\end{tabular}

Note: Same as for Table 4, except with an unrestricted variance-covariance matrix for the background noise. 
TABLE 13

\begin{tabular}{|c|c|c|c|c|c|c|}
\hline & ED1 & ED4 & 2-year & 5 -year & 10-year & 30-year \\
\hline Non-farm & $\begin{array}{c}3.08 \\
(0.20)\end{array}$ & $\begin{array}{c}6.24 \\
(0.30)\end{array}$ & $\begin{array}{c}4.46 \\
(0.20)\end{array}$ & $\begin{array}{c}5.10 \\
(0.23)\end{array}$ & $\begin{array}{c}3.85 \\
(0.18)\end{array}$ & $\begin{array}{c}2.35 \\
(0.12)\end{array}$ \\
\hline Initial claims & $\begin{array}{l}-0.33 \\
(0.02)\end{array}$ & $\begin{array}{l}-0.74 \\
(0.04)\end{array}$ & $\begin{array}{l}-0.59 \\
(0.04)\end{array}$ & $\begin{array}{l}-0.71 \\
(0.04)\end{array}$ & $\begin{array}{l}-0.58 \\
(0.04)\end{array}$ & $\begin{array}{l}-0.36 \\
(0.03)\end{array}$ \\
\hline Durable & $\begin{array}{c}0.38 \\
(0.06)\end{array}$ & $\begin{array}{c}1.00 \\
(0.13)\end{array}$ & $\begin{array}{c}0.60 \\
(0.10)\end{array}$ & $\begin{array}{c}0.83 \\
(0.12)\end{array}$ & $\begin{array}{c}0.59 \\
(0.09)\end{array}$ & $\begin{array}{c}0.31 \\
(0.06)\end{array}$ \\
\hline Emp cost & $\begin{array}{c}0.71 \\
(0.12)\end{array}$ & $\begin{array}{c}1.65 \\
(0.26)\end{array}$ & $\begin{array}{c}1.26 \\
(0.19)\end{array}$ & $\begin{array}{c}1.43 \\
(0.22)\end{array}$ & $\begin{array}{c}1.44 \\
(0.17)\end{array}$ & $\begin{array}{c}0.72 \\
(0.12)\end{array}$ \\
\hline Retail & $\begin{array}{c}0.46 \\
(0.12)\end{array}$ & $\begin{array}{c}1.08 \\
(0.14)\end{array}$ & $\begin{array}{c}0.79 \\
(0.13)\end{array}$ & $\begin{array}{c}0.71 \\
(0.14)\end{array}$ & $\begin{array}{c}0.49 \\
(0.11)\end{array}$ & $\begin{array}{c}0.29 \\
(0.08)\end{array}$ \\
\hline Retail ex. auto & $\begin{array}{c}0.33 \\
(0.11)\end{array}$ & $\begin{array}{c}0.74 \\
(0.15)\end{array}$ & $\begin{array}{c}0.64 \\
(0.11)\end{array}$ & $\begin{array}{c}1.03 \\
(0.13)\end{array}$ & $\begin{array}{c}0.95 \\
(0.11)\end{array}$ & $\begin{array}{c}0.70 \\
(0.08)\end{array}$ \\
\hline GDP & $\begin{array}{c}0.65 \\
(0.08)\end{array}$ & $\begin{array}{c}1.56 \\
(0.21)\end{array}$ & $\begin{array}{c}1.21 \\
(0.15)\end{array}$ & $\begin{array}{c}1.43 \\
(0.19)\end{array}$ & $\begin{array}{c}1.09 \\
(0.16)\end{array}$ & $\begin{array}{c}0.68 \\
(0.11)\end{array}$ \\
\hline CPI & $\begin{array}{l}-0.12 \\
(0.06)\end{array}$ & $\begin{array}{l}-0.17 \\
(0.13)\end{array}$ & $\begin{array}{l}-0.14 \\
(0.10)\end{array}$ & $\begin{array}{l}-0.09 \\
(0.12)\end{array}$ & $\begin{array}{l}-0.01 \\
(0.10)\end{array}$ & $\begin{array}{c}0.09 \\
(0.08)\end{array}$ \\
\hline Core CPI & $\begin{array}{c}0.75 \\
(0.08)\end{array}$ & $\begin{array}{c}1.67 \\
(0.14)\end{array}$ & $\begin{array}{c}1.21 \\
(0.10)\end{array}$ & $\begin{array}{c}1.40 \\
(0.14)\end{array}$ & $\begin{array}{c}1.13 \\
(0.11)\end{array}$ & $\begin{array}{c}0.78 \\
(0.08)\end{array}$ \\
\hline PPI & $\begin{array}{l}-0.01 \\
(0.06)\end{array}$ & $\begin{array}{c}0.08 \\
(0.11)\end{array}$ & $\begin{array}{c}0.03 \\
(0.08)\end{array}$ & $\begin{array}{l}-0.03 \\
(0.10)\end{array}$ & $\begin{array}{c}0.05 \\
(0.08)\end{array}$ & $\begin{array}{c}0.05 \\
(0.06)\end{array}$ \\
\hline Core PPI & $\begin{array}{c}0.69 \\
(0.08)\end{array}$ & $\begin{array}{c}1.12 \\
(0.12)\end{array}$ & $\begin{array}{c}0.78 \\
(0.10)\end{array}$ & $\begin{array}{c}1.10 \\
(0.11)\end{array}$ & $\begin{array}{c}0.91 \\
(0.09)\end{array}$ & $\begin{array}{c}0.70 \\
(0.07)\end{array}$ \\
\hline Hourly earnings & $\begin{array}{c}0.94 \\
(0.15)\end{array}$ & $\begin{array}{c}2.11 \\
(0.20)\end{array}$ & $\begin{array}{c}1.51 \\
(0.15)\end{array}$ & $\begin{array}{c}2.31 \\
(0.18)\end{array}$ & $\begin{array}{c}1.84 \\
(0.15)\end{array}$ & $\begin{array}{c}1.24 \\
(0.11)\end{array}$ \\
\hline Unemp & $\begin{array}{l}-1.23 \\
(0.11)\end{array}$ & $\begin{array}{l}-2.12 \\
(0.20)\end{array}$ & $\begin{array}{l}-1.53 \\
(0.15)\end{array}$ & $\begin{array}{l}-1.54 \\
(0.17)\end{array}$ & $\begin{array}{c}-1.04 \\
(0.13)\end{array}$ & $\begin{array}{l}-0.59 \\
(0.09)\end{array}$ \\
\hline FOMC & $\begin{array}{c}0.76 \\
(0.06)\end{array}$ & $\begin{array}{c}0.49 \\
(0.11)\end{array}$ & $\begin{array}{c}0.34 \\
(0.08)\end{array}$ & $\begin{array}{c}0.21 \\
(0.11)\end{array}$ & $\begin{array}{c}0.07 \\
(0.09)\end{array}$ & $\begin{array}{l}-0.03 \\
(0.05)\end{array}$ \\
\hline Factor & $\begin{array}{c}1.55 \\
(0.07)\end{array}$ & $\begin{array}{c}3.45 \\
(0.07)\end{array}$ & $\begin{array}{c}2.55 \\
(0.05)\end{array}$ & $\begin{array}{c}2.78 \\
(0.07)\end{array}$ & $\begin{array}{c}2.07 \\
(0.07)\end{array}$ & $\begin{array}{c}1.24 \\
(0.05)\end{array}$ \\
\hline$R^{2}$ no factor & 0.37 & 0.33 & 0.30 & 0.27 & 0.24 & 0.20 \\
\hline$R^{2}$ with factor & 0.80 & 0.97 & 0.94 & 0.82 & 0.72 & 0.55 \\
\hline
\end{tabular}

Note: Same as for Table 3, except that yield changes are calculated around a wide event window and variance-covariance matrix is unrestricted for the background noise.

For the daily window, one factor increases $R^{2}$ values for all Treasury futures. However, the contribution of the latent factor to $R^{2}$ is declining with maturity. Consistent with earlier results, Treasury futures responses exhibit a hump shape. Then we explore the implications of the latent factor for other interest rates that are available in daily frequency, such as two- and five-year swap rates (Bloomberg 2020) and the Moody's AAA corporate bond yields (Moody's 2020). The last three columns of Table 14 show the results of this exercise. Headline surprise can only explain around 10 percent of the variation in swap rates and less than 10 percent for corporate bond yields. However, adding the latent factor to the event study regression increases $R^{2}$ by 40 to 60 percent for swaps and 15 percent for corporate bond yields.

This exercise strongly shows that one latent factor improves the explanatory power of event studies regardless of the event window width, and that the news 
TABLE 14

\begin{tabular}{|c|c|c|c|c|c|c|c|c|c|}
\hline & \multicolumn{6}{|c|}{ Futures } & \multicolumn{2}{|c|}{ Swaps } & \multirow{2}{*}{$\frac{\text { Corp. }}{\text { AAA }}$} \\
\hline & ED1 & ED4 & 2-year & 5 -year & 10-year & 30-year & 2-year & 5-year & \\
\hline Non-farm & $\begin{array}{c}2.21 \\
(0.12)\end{array}$ & $\begin{array}{c}6.46 \\
(0.37)\end{array}$ & $\begin{array}{c}4.48 \\
(0.24)\end{array}$ & $\begin{array}{c}5.04 \\
(0.31)\end{array}$ & $\begin{array}{c}3.96 \\
(0.25)\end{array}$ & $\begin{array}{c}2.59 \\
(0.17)\end{array}$ & $\begin{array}{c}4.34 \\
(0.39)\end{array}$ & $\begin{array}{c}4.52 \\
(0.40)\end{array}$ & $\begin{array}{c}2.90 \\
(0.34)\end{array}$ \\
\hline Init. claims & $\begin{array}{l}-0.28 \\
(0.05)\end{array}$ & $\begin{array}{l}-1.11 \\
(0.10)\end{array}$ & $\begin{array}{l}-0.89 \\
(0.08)\end{array}$ & $\begin{array}{l}-1.12 \\
(0.10)\end{array}$ & $\begin{array}{l}-0.94 \\
(0.08)\end{array}$ & $\begin{array}{l}-0.67 \\
(0.06)\end{array}$ & $\begin{array}{l}-0.81 \\
(0.11)\end{array}$ & $\begin{array}{l}-0.89 \\
(0.13)\end{array}$ & $\begin{array}{c}-0.76 \\
(0.13)\end{array}$ \\
\hline Durable & $\begin{array}{c}0.33 \\
(0.08)\end{array}$ & $\begin{array}{c}0.89 \\
(0.24)\end{array}$ & $\begin{array}{c}0.64 \\
(0.21)\end{array}$ & $\begin{array}{c}0.73 \\
(0.22)\end{array}$ & $\begin{array}{c}0.64 \\
(0.18)\end{array}$ & $\begin{array}{c}0.46 \\
(0.11)\end{array}$ & $\begin{array}{c}0.55 \\
(0.20)\end{array}$ & $\begin{array}{c}0.40 \\
(0.23)\end{array}$ & $\begin{array}{c}0.68 \\
(0.25)\end{array}$ \\
\hline Emp cost & $\begin{array}{c}0.92 \\
(0.17)\end{array}$ & $\begin{array}{c}2.15 \\
(0.40)\end{array}$ & $\begin{array}{c}1.77 \\
(0.30)\end{array}$ & $\begin{array}{c}2.14 \\
(0.34)\end{array}$ & $\begin{array}{c}1.70 \\
(0.27)\end{array}$ & $\begin{array}{c}1.13 \\
(0.19)\end{array}$ & $\begin{array}{c}1.79 \\
(0.32)\end{array}$ & $\begin{array}{c}2.21 \\
(0.41)\end{array}$ & $\begin{array}{c}1.37 \\
(0.43)\end{array}$ \\
\hline Retail & $\begin{array}{c}0.70 \\
(0.10)\end{array}$ & $\begin{array}{c}1.88 \\
(0.21)\end{array}$ & $\begin{array}{c}1.60 \\
(0.15)\end{array}$ & $\begin{array}{c}1.75 \\
(0.20)\end{array}$ & $\begin{array}{c}1.35 \\
(0.18)\end{array}$ & $\begin{array}{c}0.82 \\
(0.14)\end{array}$ & $\begin{array}{c}1.43 \\
(0.38)\end{array}$ & $\begin{array}{c}1.58 \\
(0.31)\end{array}$ & $\begin{array}{c}1.06 \\
(0.30)\end{array}$ \\
\hline Retail ex. auto & $\begin{array}{l}-0.33 \\
(0.13)\end{array}$ & $\begin{array}{c}0.34 \\
(0.24)\end{array}$ & $\begin{array}{c}0.16 \\
(0.17)\end{array}$ & $\begin{array}{c}0.56 \\
(0.23)\end{array}$ & $\begin{array}{c}0.52 \\
(0.21)\end{array}$ & $\begin{array}{c}0.53 \\
(0.17)\end{array}$ & $\begin{array}{c}0.33 \\
(0.33)\end{array}$ & $\begin{array}{c}0.77 \\
(0.43)\end{array}$ & $\begin{array}{c}0.66 \\
(0.41)\end{array}$ \\
\hline GDP & $\begin{array}{c}0.88 \\
(0.22)\end{array}$ & $\begin{array}{c}1.42 \\
(0.40)\end{array}$ & $\begin{array}{c}1.00 \\
(0.28)\end{array}$ & $\begin{array}{c}0.93 \\
(0.36)\end{array}$ & $\begin{array}{c}0.68 \\
(0.31)\end{array}$ & $\begin{array}{c}0.41 \\
(0.23)\end{array}$ & $\begin{array}{c}1.34 \\
(0.41)\end{array}$ & $\begin{array}{c}1.36 \\
(0.54)\end{array}$ & $\begin{array}{c}0.71 \\
(0.28)\end{array}$ \\
\hline CPI & $\begin{array}{c}0.49 \\
(0.18)\end{array}$ & $\begin{array}{c}0.49 \\
(0.24)\end{array}$ & $\begin{array}{c}0.19 \\
(0.15)\end{array}$ & $\begin{array}{c}0.35 \\
(0.21)\end{array}$ & $\begin{array}{c}0.29 \\
(0.20)\end{array}$ & $\begin{array}{c}0.14 \\
(0.14)\end{array}$ & $\begin{array}{c}0.35 \\
(0.24)\end{array}$ & $\begin{array}{c}0.38 \\
(0.34)\end{array}$ & $\begin{array}{c}-0.08 \\
(0.32)\end{array}$ \\
\hline Core CPI & $\begin{array}{c}0.52 \\
(0.11)\end{array}$ & $\begin{array}{c}1.62 \\
(0.23)\end{array}$ & $\begin{array}{c}1.24 \\
(0.17)\end{array}$ & $\begin{array}{c}1.23 \\
(0.21)\end{array}$ & $\begin{array}{c}0.84 \\
(0.18)\end{array}$ & $\begin{array}{c}0.66 \\
(0.13)\end{array}$ & $\begin{array}{c}1.23 \\
(0.31)\end{array}$ & $\begin{array}{c}1.47 \\
(0.40)\end{array}$ & $\begin{array}{c}0.90 \\
(0.32)\end{array}$ \\
\hline PPI & $\begin{array}{c}0.15 \\
(0.13)\end{array}$ & $\begin{array}{l}-0.38 \\
(0.20)\end{array}$ & $\begin{array}{l}-0.33 \\
(0.15)\end{array}$ & $\begin{array}{l}-0.49 \\
(0.19)\end{array}$ & $\begin{array}{l}-0.33 \\
(0.17)\end{array}$ & $\begin{array}{l}-0.12 \\
(0.12)\end{array}$ & $\begin{array}{l}-0.44 \\
(0.27)\end{array}$ & $\begin{array}{l}-0.39 \\
(0.28)\end{array}$ & $\begin{array}{c}0.09 \\
(0.33)\end{array}$ \\
\hline Core PPI & $\begin{array}{c}0.39 \\
(0.13)\end{array}$ & $\begin{array}{c}1.10 \\
(0.19)\end{array}$ & $\begin{array}{c}0.67 \\
(0.16)\end{array}$ & $\begin{array}{c}1.07 \\
(0.18)\end{array}$ & $\begin{array}{c}1.01 \\
(0.16)\end{array}$ & $\begin{array}{c}0.89 \\
(0.11)\end{array}$ & $\begin{array}{c}0.85 \\
(0.28)\end{array}$ & $\begin{array}{c}1.05 \\
(0.29)\end{array}$ & $\begin{array}{c}0.73 \\
(0.33)\end{array}$ \\
\hline Hourly earnings & $\begin{array}{c}0.59 \\
(0.12)\end{array}$ & $\begin{array}{c}1.92 \\
(0.27)\end{array}$ & $\begin{array}{c}1.47 \\
(0.19)\end{array}$ & $\begin{array}{c}2.22 \\
(0.25)\end{array}$ & $\begin{array}{c}1.86 \\
(0.21)\end{array}$ & $\begin{array}{c}1.78 \\
(0.15)\end{array}$ & $\begin{array}{c}1.78 \\
(0.32)\end{array}$ & $\begin{array}{c}1.99 \\
(0.40)\end{array}$ & $\begin{array}{c}0.93 \\
(0.35)\end{array}$ \\
\hline Unemp & $\begin{array}{l}-0.75 \\
(0.11)\end{array}$ & $\begin{array}{l}-1.38 \\
(0.26)\end{array}$ & $\begin{array}{l}-0.91 \\
(0.19)\end{array}$ & $\begin{array}{l}-0.63 \\
(0.23)\end{array}$ & $\begin{array}{l}-0.32 \\
(0.20)\end{array}$ & $\begin{array}{l}-0.07 \\
(0.14)\end{array}$ & $\begin{array}{l}-0.96 \\
(0.30)\end{array}$ & $\begin{array}{l}-0.45 \\
(0.37)\end{array}$ & $\begin{array}{r}-0.07 \\
(0.34)\end{array}$ \\
\hline FOMC & $\begin{array}{c}0.58 \\
(0.04)\end{array}$ & $\begin{array}{c}0.36 \\
(0.08)\end{array}$ & $\begin{array}{c}0.25 \\
(0.06)\end{array}$ & $\begin{array}{c}0.15 \\
(0.08)\end{array}$ & $\begin{array}{c}0.06 \\
(0.06)\end{array}$ & $\begin{array}{l}-0.01 \\
(0.03)\end{array}$ & $\begin{array}{c}0.28 \\
(0.11)\end{array}$ & $\begin{array}{c}0.21 \\
(0.12)\end{array}$ & $\begin{array}{c}0.11 \\
(0.05)\end{array}$ \\
\hline Factor & $\begin{array}{c}1.86 \\
(0.22)\end{array}$ & $\begin{array}{c}3.77 \\
(0.34)\end{array}$ & $\begin{array}{c}2.62 \\
(0.24)\end{array}$ & $\begin{array}{c}2.87 \\
(0.46)\end{array}$ & $\begin{array}{c}2.19 \\
(0.44)\end{array}$ & $\begin{array}{c}1.16 \\
(0.33)\end{array}$ & $\begin{array}{c}7.48 \\
(0.24)\end{array}$ & $\begin{array}{c}7.29 \\
(0.25)\end{array}$ & $\begin{array}{c}3.50 \\
(0.20)\end{array}$ \\
\hline$R^{2}$ no factor & 0.14 & 0.13 & 0.13 & 0.11 & 0.09 & 0.08 & 0.10 & 0.09 & 0.06 \\
\hline$R^{2}$ with factor & 0.85 & 0.84 & 0.77 & 0.62 & 0.48 & 0.27 & 0.60 & 0.48 & 0.20 \\
\hline
\end{tabular}

Notes: Same as for Table 3, except that yield changes are calculated around a daily event window and variance-covariance matrix is unrestricted for the background noise. Last three columns of the table show the response of 2- and 5-year interest rate swaps and AAA-rated corporate bond yields to headline surprises and the latent factor, which is estimated using daily changes in futures. The sample is 1992-2018.

effects do not quickly dissipate irrespective of whether these are news observed by the econometrician.

Monthly and Quarterly Responses.-In an important paper Altavilla, Giannone, and Modugno (2017) show that news announcements explain a larger share of bond yield changes aggregated at quarterly frequency than at daily frequency because the effects of news are more persistent than other factors. In a similar vein, Hanson, Lucca, and Wright (2018) find that news announcements have different effects on the yield curve at high- and low-frequencies. Do the effects of unobserved news withstand aggregation to lower frequencies? 
We address this question by adapting the strategy of Altavilla, Giannone, and Modugno (2017). We consider the models

$$
y_{m, t}=\beta_{m}^{\prime} s_{t}+u_{t}
$$

where $y_{m, t}$ denotes the daily yield change at maturity $m$, and

$$
y_{m, t}=\beta_{m}^{\prime} s_{t}+\gamma_{m} f_{t}+u_{t}
$$

and then define a headline news index ${ }^{25}\left(H_{N, t}\right)$ and a broad news index $\left(B N I_{m, t}\right)$ as the fitted values from regressions (14) and (15), respectively. The headline news index is exactly as considered by Altavilla, Giannone, and Modugno (2017), while the broad index includes the effect of the latent news factor. We then run regressions of the form

$$
y_{m, t}^{(h)}=\alpha_{0}^{(h)} H N I_{m, t}^{(h)}+u_{t}^{(h)}
$$

and

$$
y_{m, t}^{(h)}=\alpha_{0}^{(h)} B N I_{m, t}^{(h)}+u_{t}^{(h)},
$$

where $y_{m, t}^{(h)}, H N I_{m, t}^{(h)}$, and $B N I_{m, t}^{(h)}$ are $y_{m, t}, H N I_{m, t}$, and $B N I_{m, t}$ aggregated to $h$ days, such that

$$
\begin{aligned}
y_{m, t}^{(h)} & =\sum_{i=0}^{h-1} y_{m, t-i}, \\
H N I_{m, t}^{(h)} & =\sum_{i=0}^{h-1} H N I_{m, t-i},
\end{aligned}
$$

and similarly for $B N I_{m, t}^{(h)} \cdot 26$ Note that all days are included in these regressions, including days with no announcements, for which $s_{t}=f_{t}=0$, hence, $H N I_{m, t}=B N I_{m, t}=0$.

We report the regression $R^{2}$ s after estimation of (16) and (17) with $h=1,22$, and 66, corresponding to daily and (approximately) monthly and quarterly frequencies as in Altavilla, Giannone, and Modugno (2017), in Table 15. The top panel of the table replicates Altavilla, Giannone, and Modugno (2017) result for our sample period and set of news releases: the variance share of headline news increases with horizon. The lower panel verifies that the latent news effects remain important even

\footnotetext{
${ }^{25}$ In constructing this news index, we expand the set of news announcements that we consider to include six other indications that mostly come out at times other than 8:30AM. These are capacity utilization, Conference Board consumer confidence, Michigan consumer sentiment, the National Association of Purchasing Managers index, the Philadelphia Fed index of manufacturing growth, and the trade balance. This is needed to have respectable $R^{2}$ values as we are now studying the news contribution to total yield variation at low frequencies, rather than variance conditional on having a news release. Altavilla, Giannone, and Modugno (2017) use an even richer news set and higher $R^{2}$ values but our results, presented below, are in agreement with theirs.

${ }^{26}$ Recalling that yield changes are measured from the close of the previous day to the close of the current day makes it easier to understand the time indices used in aggregation.
} 
TABLE 15

\begin{tabular}{lccc}
\hline \hline & 2-year & 5-year & 10-year \\
\hline Panel A. Headline surprises only & & & \\
$R^{2}$ 1-day & 0.08 & 0.07 & 0.05 \\
$\quad$ 1-month & 0.17 & 0.14 & 0.10 \\
1-quarter & 0.25 & 0.24 & 0.21 \\
& & & \\
Panel B. Headline surprises and factor & & & \\
$R^{2}$ & & & \\
1-day & 0.47 & 0.47 & 0.40 \\
1-month & 0.46 & 0.50 & 0.42 \\
1-quarter & 0.42 & 0.52 & 0.51 \\
\hline
\end{tabular}

Notes: The effects of news on 2-, 5-, 10-year zero coupon yields $(\tau=2,5,10)$ for 1-day $(h=1), 1$-month $(h=22)$, and 1-quarter $(h=66)$ horizon. Panel A shows the $R^{2} \mathrm{~s}$ of equation (16) when the news index is constructed using the headline surprises only and panel B shows the $R^{2}$ s of equation (17) when the news index is constructed using headline surprises and the latent factor.

Source: The sample is 1992-2018. Daily zero coupon yield curve data are from Gürkaynak, Sack, and Wright (2007).

after Altavilla, Giannone, and Modugno (2017) aggregation is taken into account. The explanatory power the $B N I$ is much larger than that of the $H N I$ at all horizons. We leave a detailed analysis of the interaction between the time aggregation and the latent news factor measurement to future work and note that taking the latent news factor into account helps explain yield curve movements at monthly and quarterly horizon as well.

\section{Conclusions}

In this paper we have proposed a new way of thinking about the impacts of macroeconomic news announcements on asset prices. The effects are assumed to come both from an observed surprise component of the announcement and from latent factors that we think of as representing unsurveyed, non-headline components of the news announcement. The inclusion of a single latent factor greatly increases the fraction of asset price movements bracketing news announcements that we can explain.

A narrow reading of this paper is that this is a contribution to econometrics of event studies. We showed that OLS and heteroskedasticity-based event studies are complements rather than substitutes. We also showed how to implement these two methods simultaneously, in a one-step procedure. We expect this to be a standard procedure when the aim is to explain as much of the asset price response as possible, without sacrificing interpretability.

A broader reading would also focus on the applications we presented. It appears that a single latent factor drives the non-headline component of the news releases in every case. This latent factor has a "hump-shaped" effect on the yield curve. Importantly, we show that when studied using our method, news can explain the vast majority of yield curve movements in the event window. Thus, we understand more, in fact most, of yield curve movements in windows involving macroeconomic data and policy releases, a goal that had hitherto been elusive. 
Although we show that news, which may not be observable to the econometrician, explains the yield curve movements in the event window, more work is needed to understand why the response has the hump shape and how exactly that shape relates to the usual level, slope, and curvature decomposition of the yield curve. We leave these interesting questions to future research, in the hope that it will benefit from the methodology that we have developed and insights that it has provided.

\section{REFERENCES}

Action Economics. 2020. Action Economics Survey. https://www.actioneconomics.com/ (accessed July 19, 2020).

Adrian, Tobias, Richard K. Crump, and Emanuel Moench. 2013. "Pricing the Term Structure with Linear Regressions." Journal of Financial Economics 110 (1): 110-38.

Altavilla, Carlo, Domenico Giannone, and Michele Modugno. 2017. "Low Frequency Effects of Macroeconomic News on Government Bond Yields." Journal of Monetary Economics 92: 31-46.

Andersen, Torben G., Tim Bollerslev, Francis X. Diebold, and Clara Vega. 2007. "Real-Time Price Discovery in Global Stock, Bond and Foreign Exchange Markets." Journal of International Economics 73 (2): 251-77.

Ang, Andrew, Geert Bekaert, and Min Wei. 2007. "Do Macro Variables, Asset Markets, or Surveys Forecast Inflation Better?" Journal of Monetary Economics 54 (4): 1163-212.

Balduzzi, Pierluigi, Edwin J. Elton, and T. Clifton Green. 2001. "Economic News and Bond Prices: Evidence from the U.S. Treasury Market." Journal of Financial and Quantitative Analysis 36 (4): 523-43.

Bauer, Michael D. 2015. "Nominal Interest Rates and the News." Journal of Money, Credit, and Banking 47 (2-3): 295-332.

Bekaert, Geert, Seonghoon Cho, and Antonio Moreno. 2010. "New Keynesian Macroeconomics and the Term Structure." Journal of Money, Credit, and Banking 42 (1): 33-62.

Bernanke, Ben S., and Kenneth N. Kuttner. 2005. "What Explains the Stock Market's Reaction to Federal Reserve Policy?" Journal of Finance 60 (3): 1221-57.

Blinder, Alan S., Michael Ehrmann, Marcel Fratzscher, Jakob De Haan, and David-Jan Jansen. 2008. "Central Bank Communication and Monetary Policy: A Survey of Theory and Evidence." Journal of Economic Literature 46 (4): 910-45.

Bloomberg. 2020. Bloomberg Database (accessed July 19, 2020).

Boyd, John H., Jian Hu, and Ravi Jagannathan. 2005. "The Stock Market's Reaction to Unemployment News: Why Bad News Is Usually Good for Stocks." Journal of Finance 60 (2): 649-72.

Campbell, Jeffrey R., Charles L. Evans, Jonas D. M. Fisher, and Alejandro Justiniano. 2012. "Macroeconomic Effects of Federal Reserve Forward Guidance." Brookings Papers on Economic Activity: $1-80$.

Carroll, Christopher D. 2007. "Macroeconomic Derivatives: An Initial Analysis of Market-Based Macro Forecasts, Uncertainty, and Risk: Comment." In NBER International Seminar on Macroeconomics 2005, edited by Jeffrey A. Frankel and Christopher A. Pissarides, 51-59. Cambridge, MA: MIT Press.

Evans, Charles L., and David A. Marshall. 2007. "Economic Determinants of the Nominal Treasury Yield Curve." Journal of Monetary Economics 54 (7): 1986-2003.

Faust, Jon, John H. Rogers, Shing-Yi B. Wang, and Jonathan H. Wright. 2007. "The High-Frequency Response of Exchange Rates and Interest Rates to Macroeconomic Announcements." Journal of Monetary Economics 54 (4): 1051-68.

Faust, Jon, and Jonathan H. Wright. 2018. "Risk Premia in the 8:30 Economy." Quarterly Journal of Finance 8 (3): 1-19.

Federal Reserve Board. 2020. Monetary Policy Announcements. https://www.federalreserve.gov/ monetarypolicy/fomc_historical_year.htm (accessed July 19, 2020).

Fleming, Michael J., and Eli M. Remolona. 1997. "What Moves the Bond Market?" Federal Reserve Bank of New York Economic Policy Review 3 (4): 31-50.

Fleming, Michael J., and Eli M. Remolona. 1999. "Price Formation and Liquidity in the U.S. Treasury Market: The Response to Public Information." Journal of Finance 54 (5): 1901-15.

French, Kenneth R. 2020. Returns on 10 Industry Portfolios. https://mba.tuck.dartmouth.edu/pages/ faculty/ken.french/ftp/10_Industry_Portfolios_daily_CSV.zip (accessed July 19, 2020). 
Fuhrer, Jeff. 2017. "Expectations as a Source of Macroeconomic Persistence: Evidence from Survey Expectations in a Dynamic Macro Model." Journal of Monetary Economics 86: 22-35.

Gertler, Mark, and Peter Karadi. 2015. "Monetary Policy Surprises, Credit Costs, and Economic Activity." American Economic Journal: Macroeconomics 7 (1): 44-76.

Gilbert, Thomas, Chiara Scotti, Georg Strasser, and Clara Vega. 2017. "Is the Intrinsic Value of a Macroeconomic News Announcement Related to Its Asset Price Impact?" Journal of Monetary Economics 92: 78-95.

Goldberg, Linda S., and Christian Grisse. 2013. "Time Variation in Asset Price Responses to Macro Announcements." NBER Working Paper 19523.

Gürkaynak, Refet S., Burçin Kısacıkoğlu, and Jonathan H. Wright. 2020. "Replication Data for: Missing Events in Event Studies: Identifying the Effects of Partially Measured News Surprises." American Economic Association [publisher], Inter-university Consortium for Political and Social Research [distributor]. https://doi.org/10.3886/E119697V1.

Gürkaynak, Refet S., Brian Sack, and Eric T. Swanson. 2005. "Do Actions Speak Louder than Words? The Response of Asset Prices to Monetary Policy Actions and Statements." International Journal of Central Banking 1 (1): 55-93.

Gürkaynak, Refet S., Brian Sack, and Jonathan H. Wright. 2007. "The U.S. Treasury Yield Curve: 1961 to the Present." Journal of Monetary Economics 54 (8): 2291-2304.

Gürkaynak, Refet S., and Justin Wolfers. 2007. "Macroeconomic Derivatives: An Initial Analysis of Market-Based Macro Forecasts, Uncertainty, and Risk." In NBER International Seminar on Macroeconomics 2005, edited by Jeffrey A. Frankel and Christopher A. Pissarides, 11-50. Cambridge, MA: MIT Press.

Gürkaynak, Refet S., and Jonathan H. Wright. 2013. "Identification and Inference Using Event Studies." The Manchester School 81 (S1): 48-65.

Hanson, Samuel G., David O. Lucca, and Jonathan H. Wright. 2018. "The Excess Sensitivity of LongTerm Rates: A Tale of Two Frequencies.” Federal Reserve Bank of New York Staff Report 810.

Hördahl, Peter, Eli M. Remolona, and Giorgio Valente. 2020. "Expectations and Risk Premia at 8:30 A.M.: Deciphering the Responses of Bond Yields to Macroeconomic Announcements." Journal of Business and Economic Statistics 38 (1): 27-42.

Kim, Don H., and Jonathan H. Wright. 2005. "An Arbitrage-Free Three-Factor Term Structure Model and the Recent Behavior of Long-Term Yields and Distant-Horizon Forward Rates." Federal Reserve Board Finance and Economics Discussion Series 2005-33.

Kuttner, Kenneth N. 2001. "Monetary Policy Surprises and Interest Rates: Evidence from the Fed Funds Futures Market." Journal of Monetary Economics 47 (3): 523-44.

McQueen, Grant, and V. Vance Roley. 1993. "Stock Prices, News, and Business Conditions." Review of Financial Studies 6 (3): 683-707.

Moody's. 2020. "Moody's Seasoned Aaa Corporate Bond Yield [AAA]." FRED, Federal Reserve Bank of St. Louis. https://fred.stlouisfed.org/series/AAA (accessed July 18, 2020).

Pearce, Douglas K., and V. Vance Roley. 1985. "Stock Prices and Economic News." Journal of Business 58 (1): 49-67.

Rigobon, Roberto. 2003. "Identification through Heteroskedasticity." Review of Economics and Statistics 85 (4): 777-92.

Rigobon, Roberto, and Brian Sack. 2003. "Measuring The Reaction of Monetary Policy to the Stock Market." Quarterly Journal of Economics 118 (2): 639-69.

Rigobon, Roberto, and Brian Sack. 2004. "The Impact of Monetary Policy on Asset Prices." Journal of Monetary Economics 51 (8): 1553-75.

Rigobon, Roberto, and Brian Sack. 2005. “The Effects of War Risk on US Financial Markets.” Journal of Banking and Finance 29 (7): 1769-89.

Rigobon, Roberto, and Brian Sack. 2008. "Noisy Macroeconomic Announcements, Monetary Policy, and Asset Prices." In Asset Prices and Monetary Policy, edited by John Y. Campbell, 335-70. Chicago: University of Chicago Press.

Swanson, Eric T. 2006. "Have Increases in Federal Reserve Transparency Improved Private Sector Interest Rate Forecasts?" Journal of Money, Credit, and Banking 38 (3): 791-819.

Swanson, Eric T., and John C. Williams. 2014. "Measuring the Effect of the Zero Lower Bound on Medium- and Longer-Term Interest Rates." American Economic Review 104 (10): 3154-85.

Tickdata. 2020. Tickdata Historic Intraday Market Data. https://www.tickdata.com (accessed July 19, 2020). 
Copyright of American Economic Review is the property of American Economic Association and its content may not be copied or emailed to multiple sites or posted to a listserv without the copyright holder's express written permission. However, users may print, download, or email articles for individual use. 